Historic, Archive Document

Do not assume content reflects current scientific knowledge, policies, or practices. 



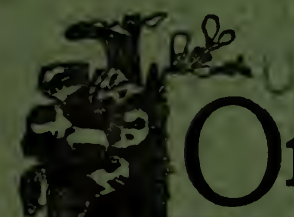

rnamental Trees,

Shrubs, Evergreens, Roses

Vines, Water-Lilies, Fruit

Trees, Small Fruits, Herbaceous

Plants, Etc. . . . . .

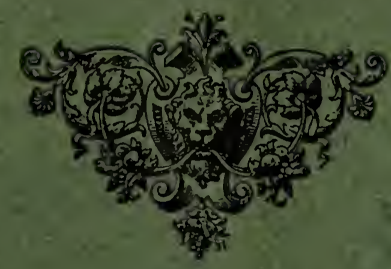

1908

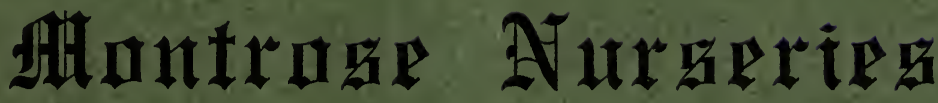

MONTROSE

Westchester County, New York 


\section{To Correspondents}

We hope to merit the continuance of the liberal patronage so long enjoyed by these Nurseries, and shall continue to make every effort to serve our customers well.

\section{CARE OF STOCH AND PLANTING}

Unpack soon as received; if dry, moisten and keep moist and out of sun and wind till planted. This is imperative with evergreens, the sap of which, being resinous, when once dried never again liquefies. If not ready to plant at once, heel-in in a trench in an inclined position, packing earth around roots; planting can then be done at leisure, taking one or two plants out at a time.

PRUNING. Cut away all bruised or broken roots with a sharp knife. It is also often necessary to cut back the branches, but just how much, depends on amount of roots. If few or poor roots, prune branches more closely, and in case of peach trees cut back severely. Roses also do better if cut back during winter or early spring. Dig a larger hole than the roots require, a little deeper than is necessary for tree, and fill in with good soil, sufficient to leave tree about same depth as when in nursery. When nearly filled with fine earth, shake tree up and down, then pack earth firmly. Should it be impossible for any reason to get earth among roots thoroughly in this way, use a "punching" stick three or four feet long and about one inch in diameter, point slightly rounded. It is a good plan to mulch all trees and plants after planting.

If manure is needed in planting, it should be well rotted and thoroughly mixed with soil. Use no manure for evergreens.

Should fruit or other deciduous trees arrive in a very dry condition, bury in moist earth for two or three days.

TERMS CASH, except by special agreement.

DISCOUNT. While we believe our prices are as low as any, considering size and quality, we will-where cash accompanies order or reaches us before shipment-allow a discount of five per cent from all prices in this Catalogue.

ORDERS to be shipped C. O. D. must be accompanied by half cash.

PACKING will be done in the best manner, for which no charge will be made, excepting for large evergreens and large shade trees.

IN COMPARING PRICES, do not forget that most firms charge for packing.

ALL GOODS delivered to cars and boats free.

THOSE who can visit our grounds will be able to select understandingly and with great advantage to themselves, especially in June and July, when everything is in its greatest beauty.

CORRESPONDENCE solicited, and if we can, consistent with character and size of order, we shall be pleased to make special prices.

REFERENCES, Peekskill National Bank, of Peekskill; Corn Exchange Bank, 42 St. branch, N. Y.; also Dun's and Bradstreet's Agencies.

OFFICE, two minutes' walk from Montrose Station.

\section{EUGENE O. PETERSON, Managor,}

Montrose, Westchoster Co. N. Y. 


\section{ORNAMENTAL DEPARTMENT}

\section{DECIDUOUS TREES}

We can furnish extra large sizes of many of the deciduous trees listed, up to three and four inches in diameter, especially of Maples, Poplars, Lindens, Ash and Elms. Prices on application.

\section{ACER. Maple}

Acer platanoides. Norway Maple. Rich, dark green; large foliage. Makes a fine symmetrical tree. 8 to $10 \mathrm{ft}$., \$I each, \$10 per doz., \$6o per 100 . Larger sizes priced on application.

Var. Geneva Purple. A beautiful new variety of the Norway Maple, holding its purple color all the season. The finest of the purple-leaved Maples. 5 to $6 \mathrm{ft}$., \$I each, \$Io per doz.

A. Schwedleri. Purple Norway [MAPLE. New growth a rich reddish purple. An elegant lawn tree. $8 \mathrm{ft}$, \$1.25 each.

A. Pseudo-platanus.

SYCAMORE MAPLE. A well-known, fast-growing tree, with large, dark green leaves. 8 to $10 \mathrm{ft}$., $\$$ I each.

A. Saccharinum. SUGAR or Rock MAPLE. One of the best and most popular Maples. Rapid, stately growth; foliage colors finely in autumn. 8 to $10 \mathrm{ft}$, $60 \mathrm{cts}$. each, $\$ 5$ per doz, 12 to I $4 \mathrm{ft}$., I I $1 / 4$ to $I \mathrm{I} / 2$ in. caliper, $\$ \mathrm{I}$ each, $\$ 9$ per doz.

A. dasycarpum. Silver Maple. The most rapid grower of the Maples. Light green foliage, silver underneath. 8 to 10 ft., 35 cts. each, $\$ 3.00$ per doz.; I $1 / 2$ to 2 in. caliper, $\$ 1.25$ each, $\$ 70$ per 100 .

A. Wieri. Wier's Cut-Leaved Maple. Partly drooping habit; finely divided leaves. Io to I $2 \mathrm{ft}$., $\$ 1.25$ each, $\$$ IO per doz., 2 to $2 x / 2$ in. caliper $\$ 2.50$.

A. rubrum. SCARlet MaPle. Numerous, small scarlet, flowers in early spring Its autumn tints are unsurpassed. Io $\mathrm{ft}$., $\$ \mathrm{I}$ each. \$9 per doz.; I 2 to I4 ft., \$I.25 each.

\section{JAPANESE MAPLES}

We call special attention to this beautiful class of Maples. They are the daintiest and most exquisite small trees, with beautifully colored and variegated foliage. There is nothing quite so charming in hardy trees as this beautiful class of plants. They are perfectly hardy, and will grow anywhere in our northern states.

Acer polymorphum atropurpureum. Blood-Leaved JapaN Maple. Rich, scarlet foliage; rather spreading growth.

- $\$ 2.00$ each.
A. purpureum dissectum. Deeply cut, purple leaves; drooping, graceful form $\$ 2$ each.

A. Reticulatum, Green and yellow variegated leaves \$I.50 each.

A. aureum. A beautiful variety, with bright golden foliage. $\$ 2.50$.

\section{ALNUS. Alder}

Alnus imperialis laciniata. IMPERIAL-CUT-LEAVED. Long, deeply cut leaves. 5 to $6 \mathrm{ft}$., $\$ \mathrm{I} .50$.

\section{AESCULUS. Horse-Chestnut}

Aesculus alba. White-flowering. Very large panicles of white flowers. An elegant shade tree. 6 to $7 \mathrm{ft}, 75 \mathrm{cts}$. 8 to Io ft., \$I.50 each.

A. rubra. A red-flowering variety; very rare and choice. 5 to $6 \mathrm{ft}$., \$I.50.

\section{ANDROMEDA. Sorrel Tree}

Andromeda arborea. The only tree of all the Andromedas. Racemes of white flowers in July; brilliant crimson foliage in fall. 75 cts.

\section{ARALIA. Hercules Club}

Aralia spinosa. A singular, small-sized tree, with very prickly stems, pinnate leaves, and immense panicles of white flowers in August. 4 to $5 \mathrm{ft}$., $75 \mathrm{cts}$. each, $\$ 7$ per doz.

\section{BETULA. Birch}

Betula alba Americana. AMERICAN White BIRCH. Somewhat irregular growth, but with care makes a fine tree for drives or lawns. Bark snowy white. 6 to $7 \mathrm{ft}$., $75 \mathrm{cts}$. each, $\$ 6$ per doz.

B. alba Europaea. European White BIRch. Very erect. A handsome tree. 6 to $8 \mathrm{ft}, 75 \mathrm{cts}$. each, $\$ 6$ per doz.

\section{CATALPA}

Catalpa speciosa. A tall, spreading, rapid-growing tree, with very large leaves, and bearing large panicles of white flowers, with red stripes and yellow centers. 6 to $8 \mathrm{ft} ., 75 \mathrm{cts}$. each, $\$ 6$ per doz.

C. Bungei. Chinese Catalpa. A remarkable species, forming a dwarf, dense, round head. 6 to $7 \mathrm{ft}$., top-grafted, $\$ 2$ each. 


\section{CORNUS. Dogwood}

For other species of Cornus, see Shrubs

Cornus florida. WhITE - Flowered Dogwood. Besides its large white flowers in May, it produces numerous scarlet berries and purple and crimson foliage in fall. 5 to $6 \mathrm{ft}$., $75 \mathrm{cts}$. each, $\$ 6$ per doz.

C. flore rubro. RED-FLowERED DoGwood. Same as above except flowers are a deep rose-color. $4 \mathrm{ft}$., $\$ \mathrm{I} .25$ each.

\section{CERCIS. Judas Tree}

Cercis Canadensis. AMERICAN JUDAs. A medium-sized tree, bearing a profusion of pink flowers in May before the leaves appear. 5 to $6 \mathrm{ft}$., \$I each, \$9 per doz.

C. Japonica. JApAnese JudAs. A valuable species; more of a shrub than a tree. The flowers are larger and in greater profusion than American. 2 to $3 \mathrm{ft}, 75 \mathrm{cts}$. each, $\$ 6$ per doz.

\section{CRAT EGUS. Hawthorn}

Crataegus. PAUL's Double RED and WhITE-FLOWERING. Fiowers numerous, rosette-like. 4 to $5 \mathrm{ft}$., $\$ \mathrm{I}$ each, $\$ 8$ per doz.

\section{CYTISUS \\ Laburnum, Golden Chain}

One of the most desirable flowering trees. Flowers bright tyellow, borıe in long racemes. 6 to $8 \mathrm{ft}$., \$I each, \$9 per doz.

\section{FAGUS. Beech}

Beeches should all be closely pruned when transplanted.

Fagus Americana. American BeEch. A magnificent tree, of large, round, spreading growth. Conspicuous for its almost white bark. 6 to $8 \mathrm{ft}$., $\$$ I each, $\$ 8$ per doz.

F. Riversi. Rivers' Purple Beech. Elegant reddish purple foliage. Very ornamental and interesting; when well established, is a rapid grower and long. lived. 4 to $5 \mathrm{ft}$., $\$ \mathrm{I} .50 \mathrm{each}, \$ \mathrm{I} 2$ per do $z$.

F. cuprea. Copper BeEch. Rich, copper-colored leaves; not as large-growing as above. 3 to $4 \mathrm{ft} ., \$ \mathrm{I} .25$.

F. asplenifolia. Fern-LEAved BeEch. Finely divided, fern-like foliage, and twiggy, well-formed growth. $3 \mathrm{ft}$., \$I.25, 5 to $6 \mathrm{ft} ., \$ 3$ each.

\section{GYMNOCLADUS. Kentucky Coffee}

Gymnocladus Canadensis. A large, well-shaped tree when well developed. Large, pinnate leaves; panicles of greenish white flowers in June. It thrives at the seashore. 5 to $6 \mathrm{ft}$., $75 \mathrm{cts}$. each.
KELLREUTERIA. Varnish Tree

Kœ1reuteria paniculata. Flat, spreading head; large pinnate leaves and immense panicles of yellow flowers in July. 4 to $5 \mathrm{ft}$., \$r.

\section{LARIX. Larch}

Larix Europaea. EUROPEAN LARCH. Rapid growth; delicate light green foliage. Should be planted in fall or early spring. 4 to $5 \mathrm{ft}$., $\$ \mathrm{I}$ each, $\$ 9$ per doz.

\section{LIQUIDAMBAR. Sweet Gum}

Iiquidambar styraciflua. A curious cork-barked tree, with star-shaped leaves, turning to brilliant shades of red and yellow in autumn. 8 to $10 \mathrm{ft}$., $75^{\mathrm{c}}$. each.

\section{LIRIODENDRON. Tulip Tree}

One of the largest of our forest trees. Very rapid growth; large, greenish yellow flowers, tulip shape; very desirable for street planting. 6 to $8 \mathrm{ft}$., $75 \mathrm{cts}$. each, $\$ 6$ per doz.

\section{NATIVE MAGNOLIAS}

The Magnolias are all very desirable trees, on account of their large, showy flowers, as well as their large, glossy foliage. Magnolias should be planted in spring, unless in sheltered places.

Magnolia glauca. Sweet Bay. A rather dwarf tree, with beautiful white, fragrant flowers. Almost or quite evergreen. 2 to $21 / 2 \mathrm{ft}$., $\$$ r each, $\$ 9$ per doz.

M. macrophy11a. This makes a tree of good size. Leaves of immense size, as are also the flowers; first of June. 6 to $8 \mathrm{ft}$., $\$ \mathrm{I}$.

M. tripetala. One of the most esteemed and useful trees. Large leaves and large white flowers latter part of May, followed by large fruit-pods of deep carmine when ripe. 6 to $7 \mathrm{ft}$., $\$ \mathrm{I}$.

\section{CHINESE AND JAPANESE MAGNOLIAS}

These are not as large-growing as the native sorts. They are best when allowed to grow in bush form.

Magnolia Soulangeana. Pinkish white flowers last of April. An elegant variety. 3 to $4 \mathrm{ft}$., $\$ 2$.

M. specioso. Large, creamy white flowers first of May. $2 \mathrm{ft}$., $\$ 2$.

M. conspicua. One of the most esteemed of all. Largé, pure white flowers last of April. 2 to $3 \mathrm{ft}$., $\$ 2$.

M. purpurea. Large purple flowers early in May. 3 to $4 \mathrm{ft}$., $\$ \mathrm{I}$ each.

Stellatta. A beautiful sort, with starshaped flowers, very rare. $3 \mathrm{ft}$., $\$ 2.50$ each. 
NEGUNDO

\section{Ash-Leaf Maple, Box Elder}

Negundo variegata. Leaves very distinctly marked with white. A remarkably attractive and ornamental tree. 4 to $5 \mathrm{ft}$., $75 \mathrm{cts}$.

\section{PAULOWNIA. Empress Tree}

Paulownia imperialis. A fine tree of large proportions and tropical appearance; immense panicles of bluish trumpetshaped flowers; fragrant; should be cut back to ground when planted. $75 \mathrm{cts}$.

\section{PLATANUS. PLANE. Sycamore}

Platanus orientalis. ORIENTal Plane. $A$ very rapid-growing, large-spreading tree. As the bark peels off it shows patches of light green and vellow. $8 \mathrm{ft}$., $75 \mathrm{cts}$. each, \$6 per doz.

\section{POPULUS. Poplar}

P. Caroliniana. Carolina Poplar. Leaves large, light glossy green; tall, upright growth. Io to I $2 \mathrm{ft}$., $50 \mathrm{cts}$. each, $\$ 3.50$ per doz.; 8 to ro $\mathrm{ft}$., $35 \mathrm{cts}$. each, $\$ 3$ per doz., \$15 per Ioo.

P. Bolleana. New. Silvery green leaves; strong upright growth; does not sucker. 8 to Io $\mathrm{ft} ., 75 \mathrm{cts}$.

P. fastigiata. LOMBARDY POPLAR. Tall, fastigiate form, sometimes reaching 120 feet. 8 to ro $\mathrm{ft}$., $60 \mathrm{cts}$. each, $\$ 5$ per doz.

\section{PRUNUS. Plum}

Prunus Pissardi. Purple-Leaved PLUM. A small tree, with beautiful dark reddish purple foliage, retaining its color throughout the entire season; the best purple-leaved tree or shrub; white flowers, followed by purple fruit. 5 to $6 \mathrm{ft}$., $50 \mathrm{cts}$. each, \$5 per doz.

\section{PYRUS. Flowering Apple}

Pyrus Malus Parkmani. ParkMAN's Flowering Crab. Pendant cluster's of rosy pink flowers in April; a very handsome, medium-sized tree. 4 to $5 \mathrm{ft}$., \$ I each, \$9 per doz.

P. coronaria Ioensis. BECHTEL's Double flowering Crab. New. Certain to become popular soon as known; blooms very young; covered in early spring with double fragrant flowers of a delicate pink. Flowers resemble roses both in form and fragrance. $4 \mathrm{ft}$., $75 \mathrm{cts}$.

\section{QUERCUS. Oak}

Quercus alba. White OAK. One of the largest and fastest-growing Oaks. The foliage takes on a light purplish hue in autumn. 4 to $5 \mathrm{ft}$., $75 \mathrm{cts}$. each; $\$ 6$ per doz.
Q. aurea. Golden-leaved OAK. Has rich golden leaves of a waxy texture. $4 \mathrm{ft}$., $\$ 1.25$.

Q. coccinea. Scarlet OAK. Most es teemed of all Oaks. Brilliant, scarlet foliage in fall. 6 to $8 \mathrm{ft}$., $\$ \mathrm{r}$.

Q. purpurea. PURPLE-LEAVED UAK. Rich dark purple foliage, retained the entire summer. 3 to $4 \mathrm{ft} ., \$ \mathrm{r} .50$.

Q. Palustus. PrN CAK. Foliage, deep green, finely divided. As the tree grows the lower branches droop gracefully, foliage turns to scarlet and yellow in autumn. 8 to ro ft., \$1.25 each, \$12 per doz.

\section{SALISBURIA. \\ Maidenhair, or Ginkgo}

Salisburia adiantifolia. A tall Japanese tree of columnar growth; the leaves resemble maidenhair fern. 8 to $10 \mathrm{ft}$., 60 cts. each, $\$ 6$ per doz.

\section{SALIX. Willow}

Salix pentandra. LAUREL LEAVED. Large shining laurel-like leaves, retained late in fall; thrives at the seashore. 7 to $8 \mathrm{ft}$., $50 \mathrm{cts}$. each, $\$ 5$ per doz.

\section{SORBUS. Mountain Ash}

Sorbus aucuparia. EuRopeAN Moun. TAIN AsH. Very showy red berries in fall. 8 to $10 \mathrm{ft}$., $75 \mathrm{cts}$. each, $\$ 6.50$ per doz.

S. quercifolia. OAK-LEAved MounTAIN AsH. A very desirable tree. 7 to $8 \mathrm{ft}$., $75 \mathrm{cts}$.

\section{SYRINGA. Lilac}

Syringa Japonica. Giant Tree Lilac. New. Immense clusters of white flowers; later than other Lilacs. 7 to $8 \mathrm{ft}$., \$1.25.

\section{TILIA. Linden}

Tilia Americana AMERICAN LINDEN. A fine, large-sized tree of rapid, dense growth; will grow in low situations. 10 to $12 \mathrm{ft}$., $\$ \mathrm{I}$ each. For larger sizes write for prices.

T. Europaea. European Linden. Compact, erect, pyramidal growth; valuable for lawn or street planting. 8 to ro ft., \$I each, \$9 per doz.

T. argentea. Silver or White-LeAved LINDEN. Rapid growth, forming a compact, round head; a fine variety with light green leaves, silvery beneath. 8 to ro $\mathrm{ft}$., $\$ 1$.

\section{ULMUS. Elm}

Ulmus Americana. American ELM. One of the most graceful of the large trees. Io to $12 \mathrm{ft}$., \$I each, \$9 per doz., 2 to 3 inch caliper, $\$ 2.50$.

U. campestris. EUROPEAN ELM. Small leaves and very twiggy. 8 to Io ft., \$I each. 


\section{WEEPING DECIDUOUS TREES}

Mountain Ash. Curious drooping form; very ornamental, especially in fall, with it bunches of red berries. \$I.

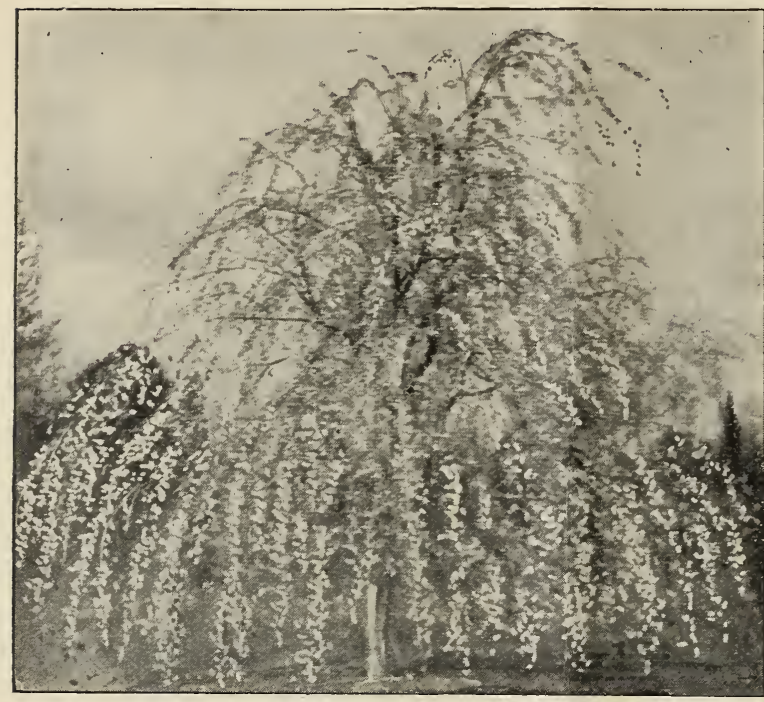

Beech. Vigorous; picturesque, making a large tree. Its manner of growth is very curious; its stem is generally straight, with irregular, drooping and spreading branches. 4 to $5 \mathrm{ft}$., $\$ 2$.

Birch. Cut-1eaved White (Betula laciniata). An elegant erect tree, with slender, drooping branches and finely cut leaves. 6 to $8 \mathrm{ft}$., $\$ \mathrm{I} .25$ each, \$Io per doz.

B., Young's Weeping. Branches droop irregularly to the ground. $\$ \mathrm{r}$.

JAPAN WEEPING CHERRY.

Cherry, Japan. This is one of the most elegant of the weeping trees, especially when in flower. Its long slender branches droop very gracefully and when about May I, it is covered with rosy, pink flowers, there is nothing that can be compared to it. Good-sized plants, $\$$ I.25.

Dogwood. A fine weeping variety of the white-flowered Dogwood; bears flowers and fruit like the upright form. 3 to 4 ft., $\$$ I.25.

E1m. Camperdown. Uniform weeping habit. Branches so overlap each other that a compact roof is formed; strong heads. \$I.5O.

Linden. White-leaved. Leaves silvery beneath. \$I.50.

Mulberry, Teas'. Forms a perfect umbrella shaped head, long slender branches drooping to the ground parallel to the stem. (See cut.) Strong heads. \$I.5O to $\$ 2.50$ each.

Willow, Babylonian. $50 \mathrm{cts}$. each, $\$ 4.50$ per doz.

W., Wisconsin. A fine, drooping, spreading form. $8 \mathrm{ft}$., $50 \mathrm{c}$. each.

W., Ki1marnock. Umbrella Willow. Strong heads, 50 cts. each, $\$ 5$ per dozen.

W., Thurlow. New. Most beautiful of the Willows, \$I.

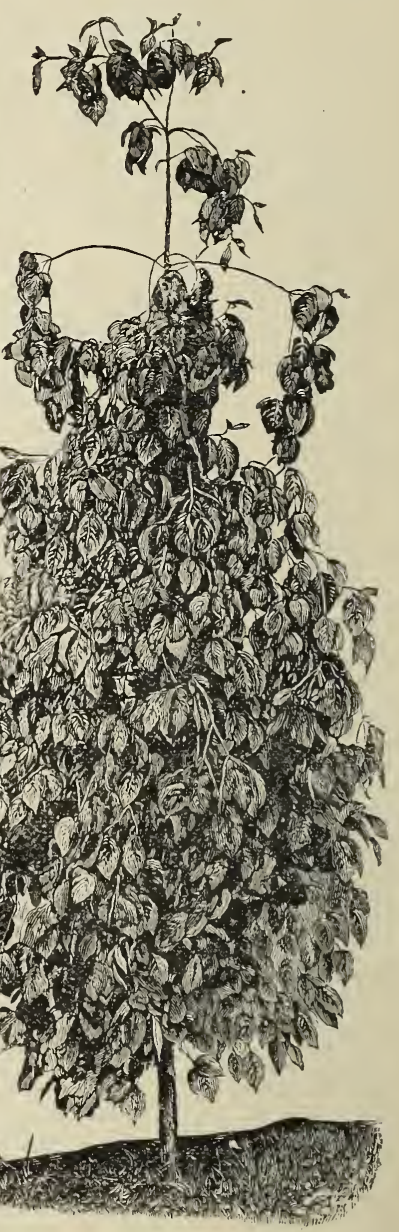

IVEEPING DOGWOOD. 


\section{ORNAMENTAL GRASSES}

Hardy Grasses are of the greatest value in lawn decoration when properly placed in the border of shrubbery or grouped in nooks and corners. The plumes form pretty winter bouquets if cut in the autumn and dried. The plants of all are strong and well developed.

Eulalia variegata. Tall, graceful growth; leaves striped white and green, longitudinally.

E. Zebrina. Zebra Grass. Unlike all other variegated grasses, having broad markings of gold across the leaf instead of lengthwise.

E. gracillima univittata. Foliage very narrow; a beautiful green, with midrib silvery white, airy and graceful.

E Japonica. Fine bluish green foliage; grows about io ft. high. Any of above 20c. each, SI.75 per doz.

Arundo Donax variegata. Very broad leaves, variegated aith golden yellow; grows 5 to $6 \mathrm{ft}$. high. $30 \mathrm{cts}$.

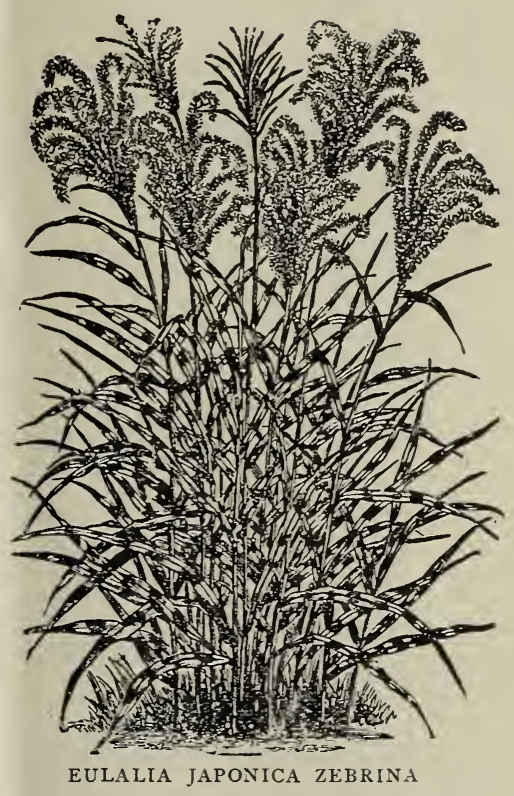

\section{FLOWERING SHRUBS}

Flowering shrubs appear to best advantage when planted in groups of a dozen or more. They may also be planted to advantage singly, and by a judicious selection of varieties succession of bloom is afforded all summer. Keep the plants in desired shape and size by a free use of the knife or shears. In laying out new grounds, shrubs should be used extensively, as they make a beautiful display the first season.

Plants we offer are all of good size and well rooted, one and one-half to six feet high, according to variety.

Althaea. Rose of Sharon. Double red, pink, purple, blue and white. These bloom from August till October. 25 cts. each, \$2 per doz.

A. foliis variegata Buistii. BuIsT's VARIEGATED ALTHÆa. Dwarfer, more compact form; flowers reddish purple, seldom expanding more than half way, but are showy. Fine for massing with other shrubs. $40 \mathrm{cts}$. each, $\$ 3.50$ per doz.

Amygdalus nana. Flowering ALMOND. Double pink-and white-flowering. 50 cts. each, \$5 per doz.

Andromeda Mariana Bell-shaped flowers in spikes; very low growth, sometimes called lily-of-the-valley shrub. 75 cts. each.

Azalea Ghent. This beautiful tribe of plants is fully the peer of the rhododendron. Flowers of nearly every shade of rose, yellow, red, etc.; very effective in groups. Strong plants, with buds, $75 \mathrm{cts}$. each, $\$ 6.50$ per doz.
Azalea mollis. A new species from Japan; large abundant flowers of red, yellow, salmon, cream, etc.; earlier than Ghent; very fragrant. Well budded plants, 75 cts. each, $\$ 7$ per doz.

A. nudiflora. Wood HoNeysuckle. Beautiful light pink flowers middle of May. An elegant shrub for massing or to plant with other shrubs. 50 cts. each, $\$ 5$ per doz.

Berberis. BARBERRy. A highly ornamental class of plants. Their blossoms are succeeded by scarlet or purple berries, persisting nearly all winter.

B. purpurea. Foliage pure purple, retained late in fall; very ornamental. 25 cts. each, $\$ 2$ per doz.

B. Thunbergi. Leaves purplish, suffused with a golden sheen in autumn; fruit dark crimson, remaining nearly all winter. Its glory of color and beautifully rounded form especially commend it. $35 \mathrm{cts}$. each, $\$ 2.50$ per doz. $\$ 15$ per 100 . 
B. Vulgaris. Common Berbery, yellow flowers in drooping racemes in May or June followed by scarlet fruit. $25 \mathrm{cts}$. each, \$2 per doz., \$I 5 per 100.

Calycanthus. StrawberRy SHRUB. Strong-growing, brownish red double flowers, having the fragrance of strawberries. $35 \mathrm{cts}$. each, $\$ 2.50$ per doz.

Chionanthus Virginica. White FRINGE. Moderate growth, rounded form; foliage rather large, pointed; numerous pure white flowers in Junelong, feathery, lace-like; very choice. 50 cts. each, $\$ 4$ per doz.

Corchorus Japonicus. JAPAN Globe Flower. Double, globular yellow flowers in April, and more or less throughout the summer; flowers resemble a yellow rose. $25 \mathrm{cts}$. each, $\$ 2$ per doz.

C. Japonicus variegatus. More dwarf than above; very striking silver-fringed leaves; single yellow flowers in June. 35 cts. each, \$3 per doz.

Corchorus, or Kerria Japonica, var. nana. Dwarf habit, single flowers; very desirable for low massing. $25 \mathrm{cts}$. each, $\$ 2$ per doz.

Callicarpa purpurea. Numerous brilliant purple berries in autumn; very choice; should be in every collection. $25 \mathrm{cts}$. each, $\$ 2.50$ per doz.

Ceanothus. New Jersey Tea. Flowers white, in bunches, and in such profusion as to almost hide the foliage. One of the best shrubs for shaded places. 50 cts. each, \$4 per doz.

Clethra alnifolia. SweET PEPPERBUSH. Growth low; numerous small spikes of white and very fragrant flowers in July. $25 \mathrm{cts}$. each, $\$ 2$ per doz.

Cornus sanguinea. RED-BRANCHED DOGWOOD. White flowers and fruit; branches bright red. Very effective in shrubbery group:. $25 \mathrm{cts}$. each, $\$ 2$ per doz.

Cornus stolonifera. Same as preceding only more erect form. Either sort, $25 \mathrm{cts}$. each, $\$ 2.25$ per doz.

C. Siberica variegata. Large foliage, broadly margined with gold; branches bright red, very showy. $50 \mathrm{cts}$.

Corylus purpurea. PURPLE FILBERT, or HAZEL. Large, rich purple leaves; holds its color well through the summer. $40 \mathrm{cts}$. each, $\$ 3.50$ per doz.

Cydonia Japonica rubra RED-FLowERING JAPAN QUINCE. Numerous, very bright-1 ed flowers in April. 35 cts. each, $\$ 2.50$ per doz.
C. Japonica alba. Pure white flowers in April; rare and choice. $40 \mathrm{cts}$. each, $\$+$ per doz.

C. Japonica tricolor. Leaves beautifully variegated with pink and white; pink flowers; quite dwarf. $35 \mathrm{cts}$. each.

Crataegus Crus=ga11i. Cockspur HAWTHORN. This has very long sharp thorns; fruit of good size. $35 \mathrm{cts}$. each, $\$ 3$ per doz.

Caryopteris Mastacanthus. BLUE SpIREA. A beautiful little shrub seldom seen; neat, clean habit, growing about three feet high. Flowers are produced in wonderful profusion in rich lavender-blue masses, from August until after hard frosts. $40 \mathrm{cts}$. each, $\$ 3.50$ per doz.

\section{DEUTZIA}

We are indebted to Japan for this valuable genus of plants. Their hardihood, fine, habit, luxuriant foliage and profusion of attractive flowers, render them the most beautiful and deservedly the most popular flowering shrubs. The flowers are produced the latter part of June in racemes four to six inches long.

Deutzia crenata flore plena. Flowers double white, tinged with rose. $35 \mathrm{cts}$. each, $\$ 2.50$ per doz., $\$$ I 5 per 100 .

D. crenata flore alba. Similar in habit to the preceding; pure white flowers, double. $25 \mathrm{cts}$. each, $\$ 2.50$ per doz.

Deutzia Fortunei. More spreading than Crenata; large, single, bell-shaped flowers in racemes. $25 \mathrm{cts}$. each, $\$ 2$ per doz.

D. Lemoinei. A recent introduction. Although the habit is dwarf, the flowers are large, pure white and produced freely. A decided acquisition. Extra strong plants, 35 cts. each, $\$ 3$ per doz.

D. scabra. Large, single, white flowers in June; broad leaves. $25 \mathrm{cts}$. each, $\$ 2.50$ per doz.

D.,Pride of Rochester. Large, double white flowecs, with the back of the petals slightly tinged with rose. It excels all the other sorts in size of flower, length of panicle, profuseness of bloom and vigorous habit. $35 \mathrm{cts}$. each $\$ 3$ per doz., $\$$ I 5 per 100.

D. gracilis. A charming species of dwarf habit; introduced from Japan by Dr. Siebold. Flowers bell-shaped, pure white, about the first of June $35 \mathrm{cts}$. each $\$ 3$ per doz.; \$I5 per Ioo.

"Enclosed please find check for your bill. The place certainly looks much improved with the new planting and we are much pleased."

Dr. Albert Shaw, Editor of the Review of Revierus, Hastings-on-Hudson. 


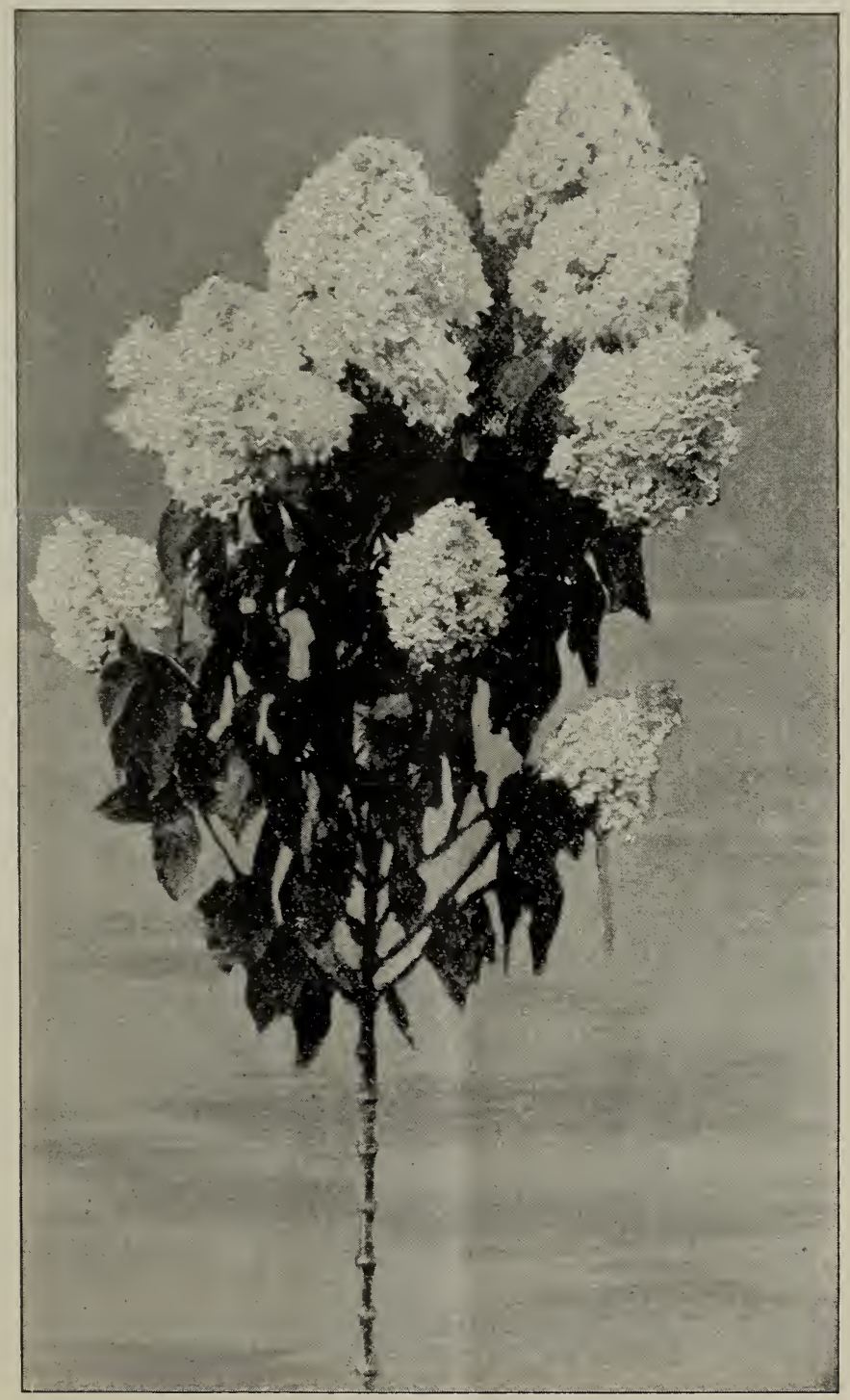

PANICULATA GRANDIFIORA. 
Desmodium penduliflorum (Lespedeza Sieboldi). JAPAN Bush Clover. Sprays of rose-colored flowers middle of September. A magnificent plant for use in beds or groups of shrubs; though not really a shrub, it grows so strong it has come to be classed as such. $35 \mathrm{cts}$. each, $\$ 3$ per doz.

Diervilla trifida. Spreading growth, somewhat dwarf, bearing loose heads of yellow flowers in early June. 35 cts. each $\$ 3$ per doz.

Eleagnus 1ongipes, Oleaster, or Silver ThORN. Berries the size of currants, of a reddish amber color, ripening in June. Good for cooking. $40 \mathrm{cts}$. each, $\$ 4$ per doz.

Euonymus Europaeus. Strawberry TREE. A large growing species; numerous bright red berries in fall. $50 \mathrm{cts}$. each.

E. alatus. Winged Euonymus. A remarkable species, with a curious wing extending down the stems between the leaves, also bearing in peculiar fashion, shining oval red berries. Foliage a beautiful reddish purple in autumn. \$I each, $\$ 9$ per doz.

Exochorda grandiflora. Profuse, pure white, flowers in May. Choice and rare 50 cts. each, $\$ 4.50$ per doz.

Forsythia viridissima. Stiff and bushlike. Flowers a light shade of yellow, opening about the third week iu April. $30 \mathrm{cts}$. each, $\$ 3.00$ per doz, $\$ 18$ per 100.

F.suspensa. A graceful drooping form; yellow flowers. $30 \mathrm{c}$. each, $\$ 3.00$ per doz. $\$ 15.00$ per Ioo.

Halesia tetraptera. Silver Bell. White bell-shaped flowers in May. Makes a large shrub or can be grown as a tree. 25 cts. each, $\$ 2$ per doz.

Hydrangea paniculata grandiflora. Very large pyramidal panicles of white flowers, changing to pink and purple. In bloom from August till frost. $35 \mathrm{cts}$. each, $\$ 3$ per doz., $\$$ I6 per Ioo.

H. nivea. Pure white flowers in umbels or nearly flat clusters; leaves silvery white beneath. $25 \mathrm{c}$. each., $\$ 2.50$ per doz.

H. Hortensia. Changeable HydraNGEA. Massive globular heads of rosecolored or sometimes blue flowers. Usually grown in pots or boxes. Should be protected or removed to cool shelter in winter. In tubs $\$ 3$ to $\$ 5$ each.

H. Hortensia Otaska. Rose-colored flowers in immense trusses in July; semiherbaceous. Protect or remove to cool shelter in winter. In tubs, $\$ 3$ to $\$ 6$ each.
Hypericum aureum. Large, rich yellow flowers; a shrubby sort with fine narrow foliage, dwarf habit, profuse bloomer. $40 \mathrm{cts}$. each, $\$ 4$ per doz.

H. Moserianum. ST. John's Wort. The finest of the species. Golden flowers $2 \mathrm{t} / 2$ inches across, blooming nearly all summer. Fine for massing or fringing shrubbery beds. Thrives well in shade, 35 cts. each, $\$ 3$ per doz.

H. multiflorum. FreE-FLowering St. JOHN's WORT. A medium-sized shrub. Yellow flowers in July and August; also thrives in shade. $25 \mathrm{cts}$. each, $\$ 2.25$ per doz.

Jasminum nudiflorum. NAKED-FLOWERING JASMINE. A slender, medium-sized shrub, bearing small yellow flowers during first mild days of March or April. Earliest blooming, hardy shrub. $25 \mathrm{cts}$. each, $\$ 2$ per doz.

Lonicera Morrowi. A species from Japan recently introduced. A decided acquisition; strong, upright grower; blooming profusely in May and June; flowers pure white, bright red berries in fall. 30 cts. each, \$2.75 per doz.

I. Tatarica. TARTARIAN HoneySUCKLE. A vigorous upright shrub, with fragrant pink or white flowers in May, followed by very ornamental orange-red berries. $25 \mathrm{cts}$. each, $\$ 2$ per doz.

L. Albertii. Low spreading growth, fine bluish-green foliage, pinkish flowers in June, Very fragrant, $25 \mathrm{cts}$. each, $\$ 2.50$ per doz.

Ligustrum ovalifolium variegata, Golden variegated foliage, very showy and handsome. $30 \mathrm{cts}$. each $\$ 2.50$ per doz.

I. Ibota. Japan species. Spreading habit, narrow leaves, remaining late in season. $25 \mathrm{cts}$. each, $\$ 2$ per doz.

I. Regelia uum. heavy, spreading, growth, black fruit, $25 \mathrm{cts}$. each, $\$ 2.50$ per doz.

I. variegata. Foliage silver-fringed. New. 25 cts. each, $\$ 2$ per doz.

Paeonia Moutan. Tree Peony. Gorgeous flowers in various shades, from white to pink and crimson. $\$$ r.25 each, $\$ 12$ per doz.

Prinos verticillatus. Black Alder. Very showy; red berries in autumn, retained nearly all winter. $60 \mathrm{cts}$. each, $\$ 5$ per doz.

Prunus triloba. Double-flowering PlUM. Very showy pink, rosette-like flowers in early May. $40 \mathrm{cts}$. each, $\$ 3.50$ per doz. 


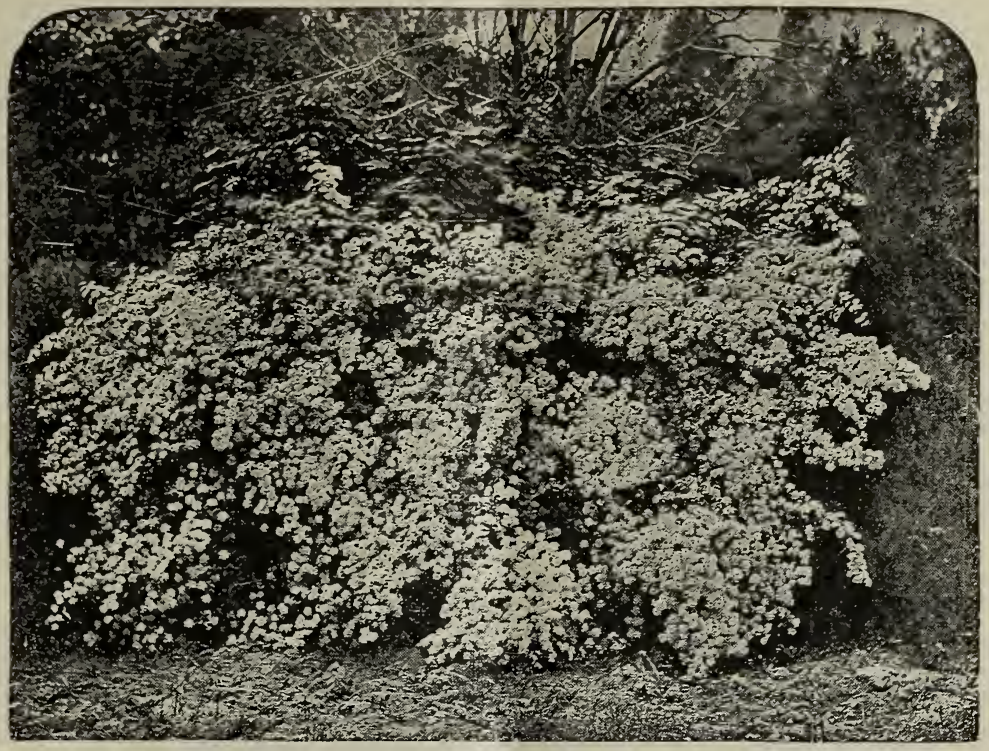

SPIRÆA VAN HOUTEII.

Philadelphus c or on a rius. Mock ORANGE, or SYRINGA. Strong-growing; pure white, very fragrant flowers in June. One of the best. $30 \mathrm{cts}$. each, $\$ 2.50$ per doz.

P. coronarius aureus. A beautiful golden-leaved variety of the preceding; a. little more dwarf. $35 \mathrm{cts}$. each $\$ 3$ per doz.

P. nanus. Very dense, compact growth; light green foliage; quite dwarf. $35 \mathrm{cts}$. each, $\$ 3.50$ per doz.

Potentilla fruticosa. Shrubby CinQUEFOIL. Erect, compact habit; long, silky pubescent leaves; flowers very pretty, bright yellow, very showy when massed. 30 cts. each, $\$ 2.50$ per doz.

Rhodotypus kerrioides. Japan. A very pretty shrub, with numerous ipure white flowers about May 15, resembling those of the Althæa, but smaller; choice and rare. $35 \mathrm{cts}$. each, $\$ 3$ per doz.

Rhus Cotinus. PURPLE Fringe, or SMOKE TREE. A low tree, with roundish head, covered with reddish purple, seedvessels like a purple mist. $40 \mathrm{cts}$. each, $\$ 4$ per doz.

R. laciniata. Cut-leaved S U M A C. Finely divided leaves, beautiful autumn tints of red and yellow. $35 \mathrm{c}$. each, $\$ 3$ per doz.
Syringa. Lilac. Common white and purple. 25 cts. each, $\$ 2$ per doz.

S. Charles $\mathbf{X}$. Large shining leaves, large trusses of reddish purple flowers. $40 \mathrm{cts}$. each.

S. Persica. Persian Lilac. Less treelike in form; upright shape, irregular; deep lilac flowers, holding their color well. 35 cts. each, $\$ 3$ per doz.

Sambucus nigra aurea. GoLDENLEAVED ELDER. Beautiful solid, golden leaves. One of the very best goldenleaved shrubs. Very picturesque and effective among other plants. $25 \mathrm{cts}$. each, $\$ 2$ per doz.

s. plumosa aurea laciniata. CUTLeaved Golden Elder. New. A beautiful new sort, large leaves, beautifully cut and of a bright golden color. Red berries in June. A great acquisition. Strong plants. $50 \mathrm{cts}$. each.

Symphoricarpus racemosus alba. White Wax. Pink flowers; white waxy berries in fall. $35 \mathrm{cts}$. each, $\$ 3$ per doz.

S. rubra. Indian CurRant. Branches literally covered in fall with red berries, causing them to droop gracefully. Very beautiful and ornamental. $20 \mathrm{cts}$. each, $\$ 2$ per doz.

"All the Shubbery furnished by you has proved very satisfactory, both to ourselves and to Mr. Langton." DiNKLE \& JewelL, Irvington-on-Hudson. 


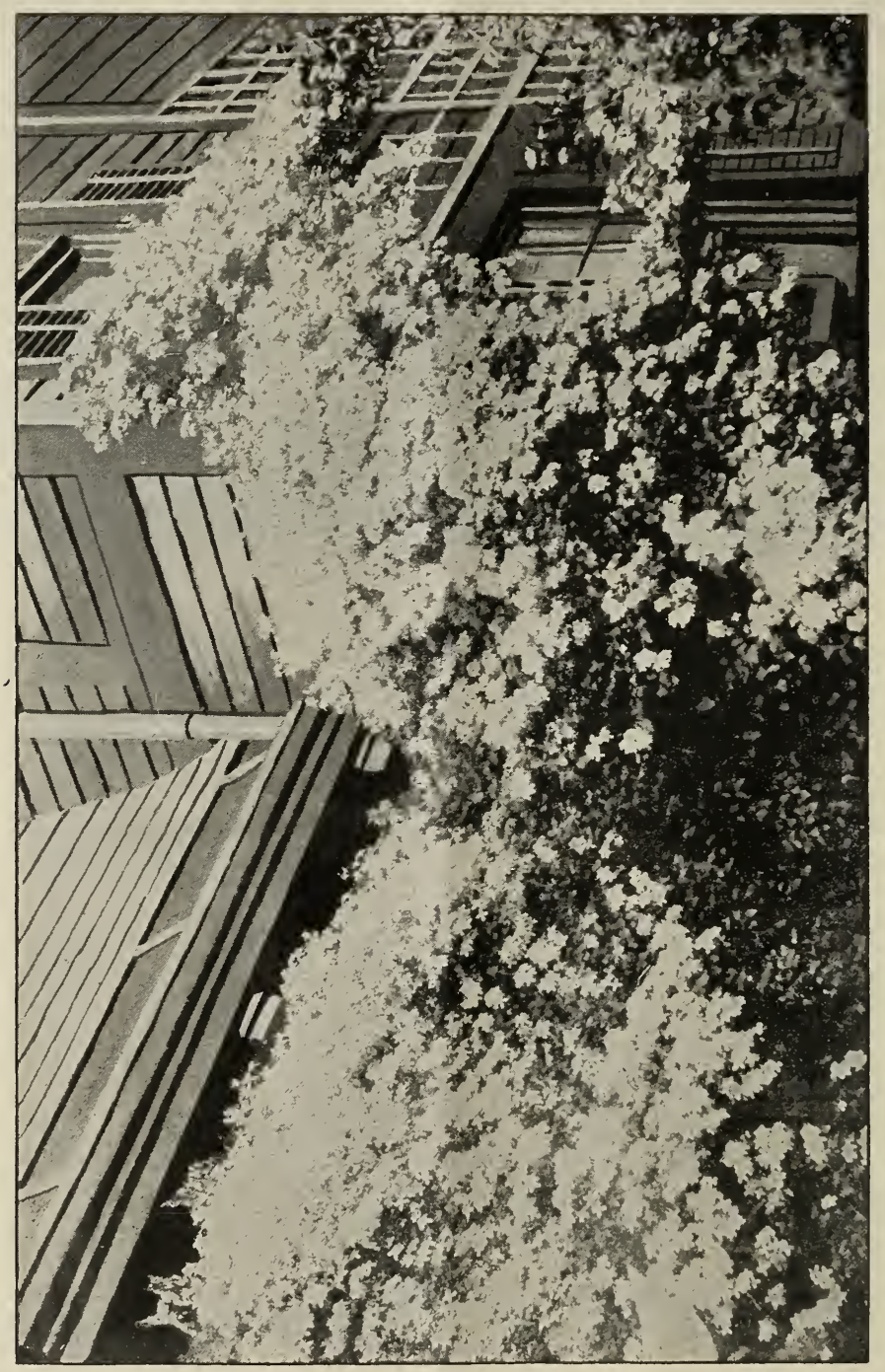

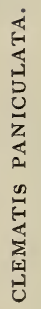


Spiraea callosa alba. Dwarf. Bears white flowers during June and July. 25 cts. each, $\$ 2.25$ per doz.

S. superba. Dwarf; delicate pink flowers in June and July. 35 cts.

S. Bumalda. Rosy pink flowers, in flat corymbs. Blooms nearly all summer. 25 cts. each, $\$ 2$ per doz.

Spiraea, Anthony Waterer. A perfect gem in every way. It casts in the shade all Spireas in brilliancy of color; a bright crimson, and is the most profuse and persistent bloomer of them all, bearing continuously large, flat clusters of lovely bloom throughout the summer and autumn. Dwarf habit; comes into bloom when not over 6 inches high. $35 \mathrm{cts}$. each, $\$ 2.50$ per doz.

S. prunifolia. BRIDAL Wreath. Numerous pure white, rozette-like flowers. 35 cts. each, $\$ 3$ per doz.

S. salicifolia. Pinkish white flowers in July. I 5 cts. each, \$I.50 per doz.

S. Thunbergii. Very numerous, white flowers in May; yellowish green shredded foliage, turning to bronze in autumn. Finest foliage effect of the Spireas. 30 ct.s. each, $\$ 2.50$ per doz., \$1 5 per 100 .

S. aurea. Very striking golden foliage. 25 cts. each, \$2 per doz.

S. Van Houttei. The most showy Spirea. Pure white, double flowers, in such profusion as to cause the branches to droop very gracefully. $35 \mathrm{cts}$. each, $\$ 2.50$ per doz., \$I 5 per I oo.

S. Frobeli. Similar to Anthony Waterer, except that the foliage shows a finer autumn coloring. $25 \mathrm{cts}$. each, $\$ 2$ per doz.

Stephenandra Flexuosa. A compactgrowi ng shrub; small, hawthorn-like leaves, bearing bunches of small, white flowers in early June. $25 \mathrm{cts}$. each, $\$ 2$ per doz.

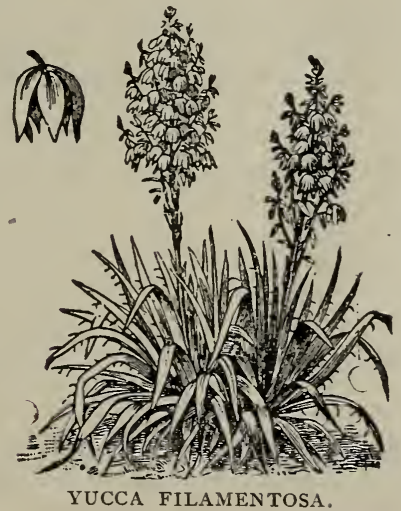

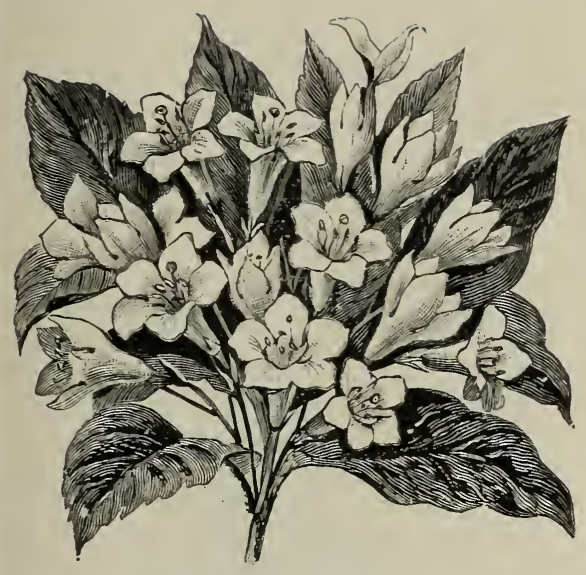

WEIGELIA ROSEA.

Tamarix Africana. African TAMARISK. Delicate feathery foliage; pink flowers in June. Should be cut back after blooming to obtain flowers another year. $30 \mathrm{cts}$. each, $\$ 3$ per doz.

T. Indica. Indian TAMARISK. Blooms in August. Strong-growing, $30 \mathrm{cts}$. each, $\$ 3$ per doz.

Viburnum dentatum. ARROW-wOOD. Very pretty when its white flowers expand in early June, followed by clusters of dark blue, almost black, fruit. $30 \mathrm{cts}$. each, $\$ 2.50$ per doz.

Viburnum molle. Soft-LEAVEd ARROW-WOOD. A native shrub of large size; pure white flowers, succeeded by clusters of blue fruit. $30 \mathrm{cts}$. each, \$2.50 per doz.

V. cassinoides. WITHE-ROD. Another native shrub of medium size, with thick, ovate, shining foliage; large, flat heads of white flowers in June, and black berries in fall. 35 cts. each. $\$ 3$ per doz.

V. plicatum. JaPAN SNowball. Numerous clusters of white flowers, borne along the stem instead of at the tips. Very handsome plicated foliage, turning to rich bronze in autumn. $50 \mathrm{cts}$. each, $\$ 4.50$ per doz.

V. Opulus sterilis. Common SNowBALL. Large balls of white flowers at the tip of each branch. $25 \mathrm{cts}$. each, $\$ 2$ per doz.

V. Oxycoccus. White flowers in large, flat heads in May. Numerous, bright red berries in fall. $35 \mathrm{cts}$. each, $\$ 3$ per doz.

Weigelia rosea. Rose-colored flowers in June in great profusion. $35 \mathrm{cts}$. each, $\$ 2.50^{-}$. per doz.

"The trees arrived in perfect condition. Both the growing and the packing are highly creditable to you." C. H. Tribits, Portchester, N. Y. 
W. amabilis. Light pink flowers in June. 25 cts. each, $\$ 2$ per doz.

W. floribunda rubra. Free-blooming, dark crimson, fuchsia-like flowers, with yellow stamens in June, and if topped off after the first flowers disappear they bloom again profusely in the fall. $35 \mathrm{cts}$. each, $\$ 3$ per doz.

W. candida. Creamy white flowers. 35 cts. each, $\$ 3$ per doz.

W. variegata. Leaves handsomely variegated with golden; light pink flowers in great profusion. 35 cts. each, $\$ 3$ per dozen.
W. Lavallei. Dark, reddish purple flowers in June, and less abundant during summer. 35 cts. each, $\$ 3$ per doz.

Eva Rathke. The best red Weigela flowers, fine dark red, blooms all summer. 40 cts. each, $\$ 4$ per doz.

Yucca filamentosa. AdAm's NeEdle. Lily-like leaves, having thread-like filaments along the edges; flowers bellshaped, greenish white, in the form of a large pyramidal spike, 3 to 6 feet high. Valuable for rockwork; large plants. 25 cts. each, $\$ 2$ per doz.; very heavy plants, $50 \mathrm{cts}$. to \$I each.

\section{HARDY VINES}

Ampelopsis Veitchi. Japan Ivy. The best vine for covering stone or brickwork. Foliage glossy green in summer, turning to bright crimson in autumn. Strong, 2year plants, $25 \mathrm{cts}$. each, $\$ 2.50$ per doz., \$1 5 per 100. Special prices on large quan. tity.

A. quinquefolia. Virginia Creeper. Valuable for covering old walls, stumps, etc. Its autumn tints are very ornamental. Strong plants, 25 cts. each, $\$ 2$ per doz.

Akebia quinata. Small, shining, subevergreen leaves. Small, purple very fragrant flowers in June. 35 cts.

Aristolochia Sipho. Durchman's Pipe. Large, dense foliage; curious pipe-shaped, yellowish brown flowers in July. Strong plants, 50 cts.

Bignonia radicans. TRUMPET VINE. Clusters of scarlet, trumpet-shaped flowers in July and August; clings tightly to whatever its growing shoots touch. 30 cts. each, $\$ 2.50$ per doz.

Clematis. Duchess of Edinburgh. Best double white; fragrant. 75 cts.

C. Henryi. Large, white flowers. 60 cts.

C. Jackmani. Large, dark purple flowers. 60 cts. each, $\$ 5$ per doz.

C. Mad. Edouard Andre. New. Large, clear red; profuse bloomer. $75 \mathrm{cts}$. each, $\$ 7$ per doz.

C. paniculata. Of strong, vigorous growth. Flowers white, star-shaped, in large clusters or masses, almost hiding the foliage. Very fragrant; perfectly hardy. Strong plants, 35 cts. each, $\$ 2.50$ per doz.

Euonymous radicans. Foliage green, of ten edged with silver; very hardy. Use- ful in shaded places. Strong plants. $35^{\mathrm{cts}}$ each, $\$ 2.50$ per doz.

E. radicans variegata. An evergreen creeper with silvery variegated leaves; valuable for carpet bedding, rockwork, borders, etc. 25 cts. each, $\$ 2.50$ per doz.

Hedera Helix. English Ivy. Large, dark green foliage retained all winter. Strong plants, 25 cts. each, $\$ 2.50$ per doz.

Lonicera Halliana. HaLL'S HoneysUCKLE. Yellow and white flowers nearly all summer; very fragrant; nearly evergreen. 25 cts. each, $\$ 2$ per doz., $\$$ I 2 per 100.

L. Japonica variegata. Foliage variegated with gold and white; beautiful autumn tints. $25 \mathrm{cts}$. each, $\$ 2.50$ per doz.

L. sempervirens. Scarlet Trumpet HONEYSUCKLE. Scarlet flowers all summer; very desirable. $30 \mathrm{cts}$. each, $\$ 3$ per doz.

Periwinkle. Sometimes called Myrtle. Bright green, glossy leaves, retained all winter; clear blue flowers in April and May; useful for covering banks, rocks, etc. Does well in shade under trees. 15 cts. each, \$I per doz., \$6 per Ioo.

Wistaria frutescens. AMERICAN WISTARIA. Blue flowers. $40 \mathrm{cts}$. each, $\$ 3.50$ per doz.

W. Multijuga. JAPANESE Wistaria. Flowers light purple, in long racemes, in May. $40 \mathrm{cts}$. each, $\$ 3.50$ per doz.

W. Sinensis. Chinese Wistaria. Best of all. Purplish white flowers in May. 40 cts. each, $\$ 3.50$ per doz.

W. Sinensis alba. A rare sort with pure white flowers. $50 \mathrm{cts}$. each, $\$ 5$ per doz.

"The Privet you shipped last week, at the order of Prof. Oldrini, was received and has been planted. It is very satisfactory, and I wish tu know if you can furnish me 500 more of the same." 


\section{EVERGREEN SHRUBS}

Azalea amoena A dwarf shrub with small, dark green leaves, changing to bronze in winter. Numerous dark red or claret-colored flowers in May. Strong plants, 75 cts. each, $\$ 6$ per doz.; extra large plants, \$I to 2.50 each.

Daphne Cneorum. Verydwarf-spreading habit; small leaves. Flowers a beautiful pink and deliciously fragrant, beginning to bloom about May $\mathrm{I}$, continuing in flower for several weeks, and an occasional flower during the summer. Strong plants, 75 cts. each, $\$ 6$ per dozen.

Kalmia latifolia. Mountarn LAUREL. Large clusters of pinkish white flowers in June; very hardy and easily transplanted. This-barring, perhaps, the rhododendron -is the most beautiful and satisfactory evergreen shrub; very easy to transplant, and is never winter-killed. I 8 to 24 in., $\$ 1.25$ each, \$10 per doz.; large bushy plants, $\$ 1.50$ to $\$ 3$.

Mahonia aquifolia. Holly-LeAved MAHONIA. Shiny green, prickly leaves, turning to bronze and red in autumn; clusters of yellow flowers in May. I6 to 20 in., 50 cts. each, \$4 per doz.

M. Japonica. Broader foliage than above, and of lighter color; the yellow flowers are followed by bunches of bluish berries. 16 to 20 in., $40 \mathrm{cts}$. each, $\$ 4$ per doz.

Rhododendrons. A relative of the Laurel, but larger flowers in larger clusters of various shades of red, purple and white. Very effective planted in groups, especially if fringed with Azalea mollis, and when in flower produce an effect to be remembered. We offer only such sorts as have proven hardy in this climate. Plants with buds, \$I.50 each, \$I 2 per doz.

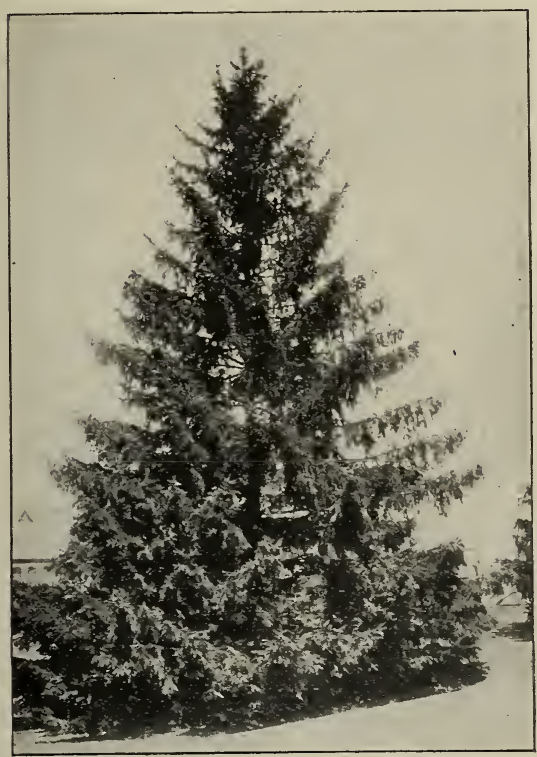

NORWAY SPRUCE.

For larger quantity, write for prices

\section{EVERGREENS}

Arborvitae American. 2 to $3 \mathrm{ft}$, 50 cts. each, $\$ 5$ per doz., $\$ 30$ per Ioo; 5 to 6 ft., \$r.25 each.

A. Siberian. Slow growth; very compact; pyramidal form. 2 to $3 \mathrm{ft}$., \$I each.

A. Globosa. Dwarf; globe-shaped; very dense. I 5 to 18 in., $50 \mathrm{cts}$. each; $\$ 5$ per doz.

A. Hoveyi aurea. Hovey's Golden ARBORVIT $Æ . \quad$ Slow growth; compact; constant golden foliage, 18 in., 25 cts. each, $\$ 2.50$ per doz., $\$ 15$ per I00; 24 to 30 in., 60 its. each.

A. elegantissima aurea. RoLLINSON'S GOLDEN ARBORviT $Æ$. Bright golden, changing to a beautiful copper in autumn. $2 \frac{1}{2}$ to $3 \mathrm{ft}$., \$I each.

A. pyramidalis. Pyramidal ArBorVITÆ. Very compact, pyramidal form; bright green foliage; 3 to $4 \mathrm{ft}$., $\$$ I each.
A. Reidii. Compact; fine foliage, bright green; slow growth. I 8 in., $75 \mathrm{cts}$. each, $\$ 7$ per doz.

A. Standishii. Upright, pyramidal form; foliage tinged with copper; very desirable. $3 \mathrm{ft}$, \$I each, \$9 per doz.

A. occidentalis aurea. PEABODY's ARBORviT E. Compact, pyramidal form; very bright golden foliage $r$ e $t$ a in ed throughout the year; one of the best golden varieties. 2 to $2 \mathrm{I} / 2 \mathrm{ft}$., $\$ \mathrm{I}$ each, $\$ 9$ per doz.

A. occidentalis E11wangeriana. Tou THUMB ARBORvitæ. Somewhat dwarf, but making a larger tree or bush than Globosa; very compact; dark green foliage; valuable for grouping with other dwarf evergreens. $2 \mathrm{ft},{ }^{2} \mathrm{cts}$. each.

"The Cemetery order was A No. I, in every respect, and I am very much pleased." 
Abies alba. White Spruce. Fine, compact, pyramidal form; bluish foliage. to $5 \mathrm{ft}$., $\$ 2.25$ each.

A. a 1 b a gloriosa. A golden-tipped White Spruce. $2 \frac{1}{2}$ to $3 \mathrm{ft}$., $\$ 2$ each.

A. Alcockiana. Moderate pyra-midal growth; leaves deep green above somewhat concave, streaked with glaucous, yellow bands below. A choice and curious evergreen. $21 / 2$ to $3 \mathrm{ft}$., $\$ 2$ each.

A. Douglasii. D o u g a s' Spruce. Large, conical form; branches numerous, spreading horizontally; leaves light green above, glaucous below. 18 in., $75 \mathrm{cts}$. each; 2 to $3 \mathrm{ft}$., \$I to $\$ \mathrm{I} .50$.

A. Gregoriana. Gregory's Spruce. Dwarf, hemispherical form, very dense growth; one of the best. \$I each.

A. pungens. (Picea pungens). ColoRADO Blue SPRUCE. Moderately dense growth and pyramidal form like the White Spruce; foliage of a rich blue or sagecolor; hardy; a most charming evergreen. $2 \mathrm{ft}$., $\$ 2$ each; $3 \mathrm{ft}$., $\$ 4$ to $\$ 5$ each.

A. concolor. The leaves or needles are very long and of a most beautiful grayish blue tinge. $2 \mathrm{ft}$., $\$ \mathrm{I} .50$ each.

A. $\mathbf{i}$ g r a pumila. DWARF BLACK SPRUCE. Very dwarf; a cushion or ball of compact, small, dark green foliage. The most interesting of all dwarf Spruces. \$I each, $\$ 9$ per doz.

A. Canadensis. HEmLock S P R C E. Delicate, spray-like foliage, distinct from all other trees. A beautiful lawn tree or hedge plant. 4 to $5 \mathrm{ft}$., $\$ \mathbf{I} .50$ to $\$ 2.50$ each, \$1 5 per doz; $21 / 2$ to $3 \mathrm{ft}$., $75 \mathrm{cts}$. each, $\$ 7$ per doz., $\$ 40$ per 100 .

A. Canadensis Sargentii pendula. SARGent's WeEping Hemlock. Permanent weeping habit, like an evergreen fountain; one of the choicest and most beautiful of evergreens; good-sized plants, $\$ 2.50$ to $\$ 5$ each.

A. excelsa. Norway Spruce. M o s t popular and well-known evergreen; rapid pyramidal growth; valuable for hedges and screens as well as a beautiful lawn tree; very hardy; well-furnished trees. 4 to $6 \mathrm{ft}$., $\$ \mathrm{I} .50$ to $\$ 5$ each; 3 to $4 \mathrm{ft}$., $75 \mathrm{cts}$. to $\$ 3$ each; $\$ 8$ to $\$ 20$ per doz.; 2 to $3 \mathrm{ft}$., $25 \mathrm{cts}$. to $75 \mathrm{cts}$. each, $\$ 2.50$ to $\$ 8$ per doz. Prices per 100 given on application.

A. excelsa pendula. Weeping Spruce. Generally upright habit, very distinct, drooping branches; an elegant and curious tree. \$I.50 each.
A. orientalis. OrIEntal or EAstern SPRUCE. Fine, dark green foliage; more dense than Norway, somewhat slower growth; an elegant lawn tree. \$2 each.

Juniperus Hibernica. I R IS H JUNIPER. Very close, upright, slender growth, with a silvery glaucous appearance. A charming tree for rockwork and columnar effect. $3 \mathrm{ft}$., \$I each, \$9 per doz.; $2 \mathrm{ft}$., $50 \mathrm{cts}$. each, \$5 per doz.

J. Suecica. Swedish Juniper. A little more spreading, and foliage a brighter green than above. $3 \mathrm{ft}$, \$I each, $\$ 9$ per doz.

J. argentea variegata. SILvER VARIEGATED JUNIPER. Tufts of white mingled with green; curious and choice. 2 ft., \$1.25.

J. Sabina. Savin Juniper. Low growth; wide-spreading; dark green foliage; well adapted for rockwork and hillsides. 75 cts. each, \$8 per doz.

J. Japonica. JAPAN. Small, compact, not unlike a Retinospora. Very desirable for rockwork and miniature plantations. Rare and choice. $3 \mathrm{ft}$., $\$ \mathrm{I} .25$ each.

J. Canadensis. Low growth; spreading open head; pale green foliage; choice. I 8 to 24 in., 75 cts. each.

J. aurea. A beautiful golden variety of the above. I 8 in., \$I each; \$9 per doz.

J. prostrata. Prostrate Juniper. A low shrub, trailing along the ground, not rising more than 6 or 8 inches high, but spreading over a large space; very choice. 75 cts. each, $\$ 6.50$ per doz.

Picea Nordmanniana. NordmanN's Silver FIR. Slow growth while young, large horizontal branches, dark green, massive foliage. The contrast of its old and new growth is most charming. $\$ 1.50$ each.

Picea balsamea. BALsam FIR. Bluish green foliage; rapid growth. $3 \frac{1}{2}$ to $4 \mathrm{ft}$. $\$ 1$ each.

Pinus Strobus. White Pine. Well. known stately evergreen. 4 to $5 \mathrm{ft}$, $\$ 2$ each, \$I 8 per doz.

P. Austriaca. Austrian Pine. Large, roundish form; dark glossy leaves. 4 to $5 \mathrm{ft}, \$$ I. 50 each, $\$ 14.00$ per doz.; $21 / 2$ to $3 \mathrm{r} / 2 \mathrm{ft} ., 75 \mathrm{cts}$. each, $\$ 8$ per doz.

P. sylvestris. Scotch PINe. A wellknown variety; short leaves of bluish green; very rapid growth. 4 to $5 \mathrm{ft}$. $\$ \mathrm{t}$ each, $\$ 9$ per doz., $2 \frac{1}{2}$ to $31 / 2 \mathrm{ft}$., $60 \mathrm{cts}$. each, $\$ 6$ per doz.

P. Cembra helvetica. Swiss Stone

"Shipment of Shrubs arrived in excellent condition, and I wish to say that they exceeded my expectations.' HENRY VIER, White Plains, N. Y.

"The plants you sent here are very satisfactory. The Quartermaster is very much pleased." A. J. Rhodes, West Point, N. Y. 
Pine. Erect, regularly branched. A handsome conical tree, with dark green thick foilage. \$1.50 each.

P. Mughus. Mugho Dawrf Pine. Low-growing, broad, spreading; nore of a large pine bush than a tree; good-sized plants. $75 \mathrm{cts}$. each, \$6 per doz.
Retinospora decussata. Small, very dense, compact; remarkable for the color of its foliage, a bluish green in summer, changing to violet-purple in autumn. 75 cts. each, $\$ 8$ per doz.

R. ericoides. HEATH-LIKE JAPAN CYPRESS. Conical, compact form; desirable

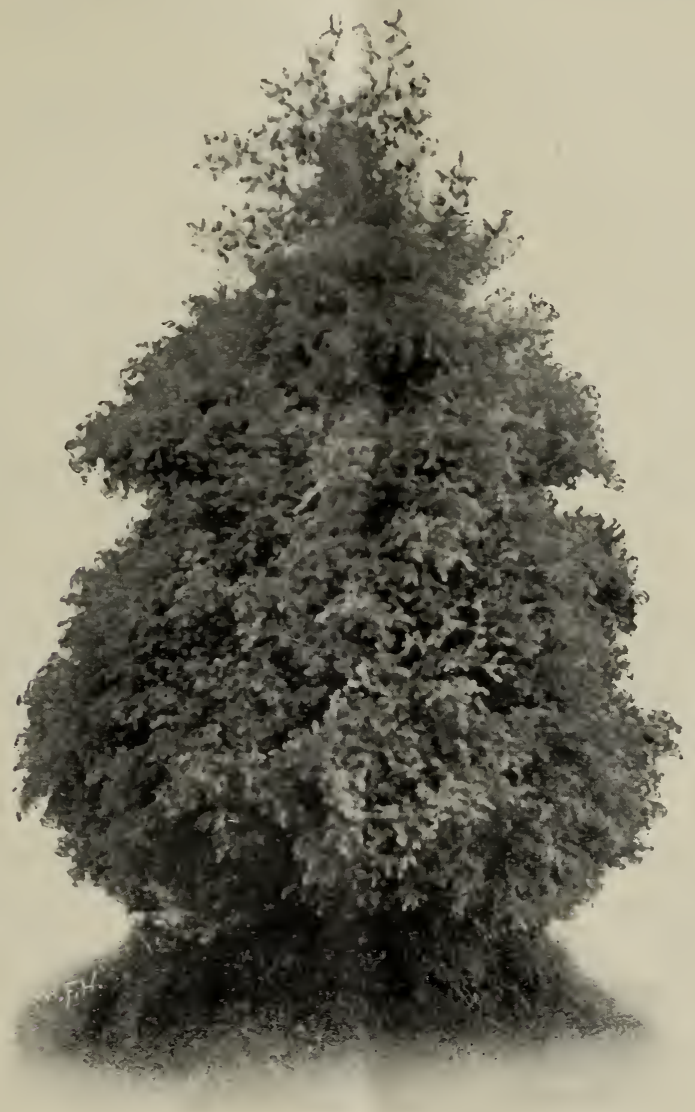

RETINOSPORA.

\section{RETINOSPORA. Japan Cypress}

A most interesting class of evergreen, many of them being of dwarf habit and adapted to small places. There are many varieties of tints and variegation among them, and they are all easily transplanted and perfectly hardy. Should be in every collection. for contrast from its violet-red color in winter. 2 to $2 \mathrm{r} / 2 \mathrm{ft}$., $60 \mathrm{cts}$. each, $\$ 6$ per doz.

R. filifera THREAD-BRANCHED JAPAN CYPRESS. A beautiful tree, with bright green foliage. It is pyramidal in outline and particularly graceful, as the.ends of its shoots droop in long filaments. 2 to 3 ft., \$I each, \$9 per doz.

"After careful selection we now have shade trees, which are growing well and in every way satisfactory. Thank you for your courtesies in the matter." 
R. filifera aurea. Golden THREADBRANCHED JAPAN CYPRESS. One of the handsomest of the family. It has all the gracefulness of the last and branches of a beautlful golden. It is very dwarf. $\$ 1.50$ each.

R. pisifera aurea. A fine variety, with branches tipped with bright golden, flat wavy foliage. $3 \mathrm{ft}$., $\$$ I. 50 each.

R. squarrosa. Soft bluish green foliage, very dense; contrasts beautifully with the darker evergreens, very striking. $2 \mathrm{ft}, 75$ cts. each, $\$ 8$ per doz.

R. plumosa. Plume-like Japan CyPRESS. Graceful, delicate glaucous foliage. $2 \mathrm{ft}$., $75 \mathrm{cts}$. each, $\$ 6$ per doz.

R.plumosa aurea. Golden PlumeLIKE JAPAN CYPRESS. A very beautiful and valuable variety. Its shoots are bright golden tinted through the year; unsurpassed for massing and for hedges. I 5 to 18 in., 50 cts. each, $\$ 4.50$ per doz.; $21 / 2$ to $3 \mathrm{ft}$., $\$ \mathrm{I}$ to $\$ 3$ each.

For larger or smaller sizes than those mentioned above, or evergreens for screens and hedges, write for special prices.

\section{SPECIMEN EVERGREENS}

Having given special attention to growing extra fine evergreens to supply a growing demand for something a little finer than is usually sent out, we are now prepared to furnish some extra-fine specimens of many of above varieties in sizes from 2 to 10 feet high. These have been sheared frequently, with a view to symmetry, and are exceptionally fine for immediate effect. Prices given on application.

\section{HEDGE PLANTS \\ DECIDUOUS}

Privet, California. The best all-round hedge plant; hardy; a rapid grower and nearly evergreen. Plants we offer are extra stocky and exceedingly well rooted. Plants 2 to $21 / 2 \mathrm{ft}$., $\$ 4$ per Ioo, $\$ 35$ per $\mathrm{I}, 000 ; 3$ to $4 \mathrm{ft}$., very stocky, $\$ 6$ per roo.
R. obtusa. A most beautiful evergreen with graceful, fern-like foliage. 2 to 3

R. obtusa nana. A weird little tree of irregular, picturesque growth, and blackgreen foliage. $18 \mathrm{in}$., $\$ 1.50$ each.

R.obtusa nana aurea. Same as above, with beautiful golden foliage. $\$ 4.5 \mathrm{C}$

Taxus Canadensis. Canadran Yew. Low spreading; bushy; seldom more than 4 feet high, thickly covered with dark 政 leaves. $\$ 9$ per doz

ing tree with rich, dark glossy green foli$\$ 1.25$ each

YEw color in June is unsurpassed by any other variegated evergreen. I 2 to 15 in., \$I each.

\section{For larger quantities, write for prices.}

\section{HARDY HERBACEOUS AND BULBOUS PLANTS}

Bleeding Heart. An old but beautiful hardy plant. $20 \mathrm{cts}$. each, $\$ 2$ per doz.

Herbaceous Peonies. Red, white and pink. Extra strong, $35 \mathrm{c}$. ea., $\$ 2.75$ per doz.

Chrysanthemums, Pompon(Artemesias). 15 cts. each, $\$ 1.50$ per doz.

Daisy, English. Dwarf; pink, red and white; blooms very early and continuously. I 5 cts. each, $\$ 1.50$ per doz.
Iris. Hardy sorts, $20 \mathrm{cts}$. each. $\$ \mathrm{I} .75 \mathrm{per}$ doz.

Lily-of-the-valley. Pips. 60 cts. per doz. $\$ 4$ per roo.

Monarda. Horse-mint, or Balm. A strongly scented herb, with crimson and purplish flowers. Io cts. each, \$I per doz.

Phlox, Assorted Varieties. Early and late-flowering. I 5 cts. each, $\$$ I.50 per doz.

"The box of Shrubs arrived in good order, and are very satisfactory in every way." 
P. subulata. Moss Pink. Evergreen moss-like foliage; grows about 6 inches high; fine for rockwork and carpeting. Strong clumps ro cents. each, \$I per doz.

Rudbeckia, Golden Glow. A glorious new plant bearing a profusion of double yellow flowers all summer. $8 \mathrm{cts}$. each, 50 çts. per doz.

Sweet Violets. Double hardy sorts. Blooming clumps, 25 cts. each, $\$ 2.50$ per doz.

\section{HARDY ROSES}

We offer below a select list of such sorts as have been found to be hardy in this climate, and that have proven satisfactory to grow out of doors. Plants we offer are strong two and three years old, except where noted, and will bloom the first season.

Price, except where noted, $25 \mathrm{cts}$. each, \$2.50 per doz.. \$16 per 10o. Extra large plants $35 \mathrm{cts}$. each, $\$ 3.50$ per doz.

BABY RAMBLER The new everblooming dwarf Crimson Rambler. This is the best hardy bedding Rose in existence. It is constantly in bloom from June until frost. The most valuable and desirable novelty of the age. Strong, one-year field-grown plants, 50 cts. each, 3 for $\$ 1.25$; heavy, two-year field-grown plants, $75 \mathrm{cts}$. each.

\section{HYBRID PERPETUALS}

The word "perpetual" is, perhaps, somewhat misleading, as only a few sorts under this head are really perpetual. Those marked with a star (*) bloom practically from June till frost.

* Anne de Diesbach. Bright clear pink, large and full.

Geveral Jacqueminot. Bright crimsonscarlet; very free bloomer.

General Washington. Bright crimson. John Hopper. Carmine-rose.

* Mme. Gabrielle Luizet. Delicate silvery pink, heightened at the center; elegant in bud. One of the sweetest and most beautiful Roses.

Magna Charta. Pink; very large.

* Mrs. John Laing. Delicate pink; fine form, especially in bud; without doubt the best bloomer among this class of Roses; very fragrant. $35 \mathrm{cts}$.

Jules Margottin. Bright red.

Prince Camille de Rohan. Very dark velvety crimson.

Margaret Dickson. New. Pure white; extra large and fine.

* Olrich Brunner. Bright cherry-red.

* Pau1 Neyron. Large dark rose.

* Marshall P. Wilder. Crimson-vermilion, exquisitely shaded and richly perfumed. $35 \mathrm{cts}$.

* Frar Kar1 Dreuschki. Fine white, long pointed buds, plant a vigorous grower, good bloomer. $35 \mathrm{cts}$.

* Perle des Blanches. White, changing to flesh-color. $35 \mathrm{cts}$.

\section{SUMMER ROSES}

Madame P1antier. Very vigorous grower; flowers very double; pure white; produced in clusters; very fragrant.

Persian Yellow. Bright yellow.

\section{MOSS ROSES}

Salet. Pale rose; a good autumn bloomer.

Crested. Rose color; buds beautifully formed and very mossy.

Perpetual White. Blooms in clusters; buds well mossed.

\section{HYBRID TEAS}

These should be protected in winter with leaves or litter. They are all constant or perpetual bloomers.

Strong, field-grown plants, 35 cts. each, \$3 per doz.

Duchess of Albany. New. A sport from La France, which it closely resembles, except that it is darker.

La France. Beautiful silvery rose color, lightest inside; beautiful in the bud.

Kaiserin Augusta Victoria. This is one of the finest and largest white Roses; buds large size, long and pointed.

Meteor. New. Rich dark crimson.

Gloire de Dijon. A grand Rose of somewhat climbing habit; color a combination of salmon, buff and orange; large, very double and deliciously fragrant.

"The 2000 Privet for Mr. Corbin have reached their goal and in good shape, and the plants were found O. K. a you told me they would be." 


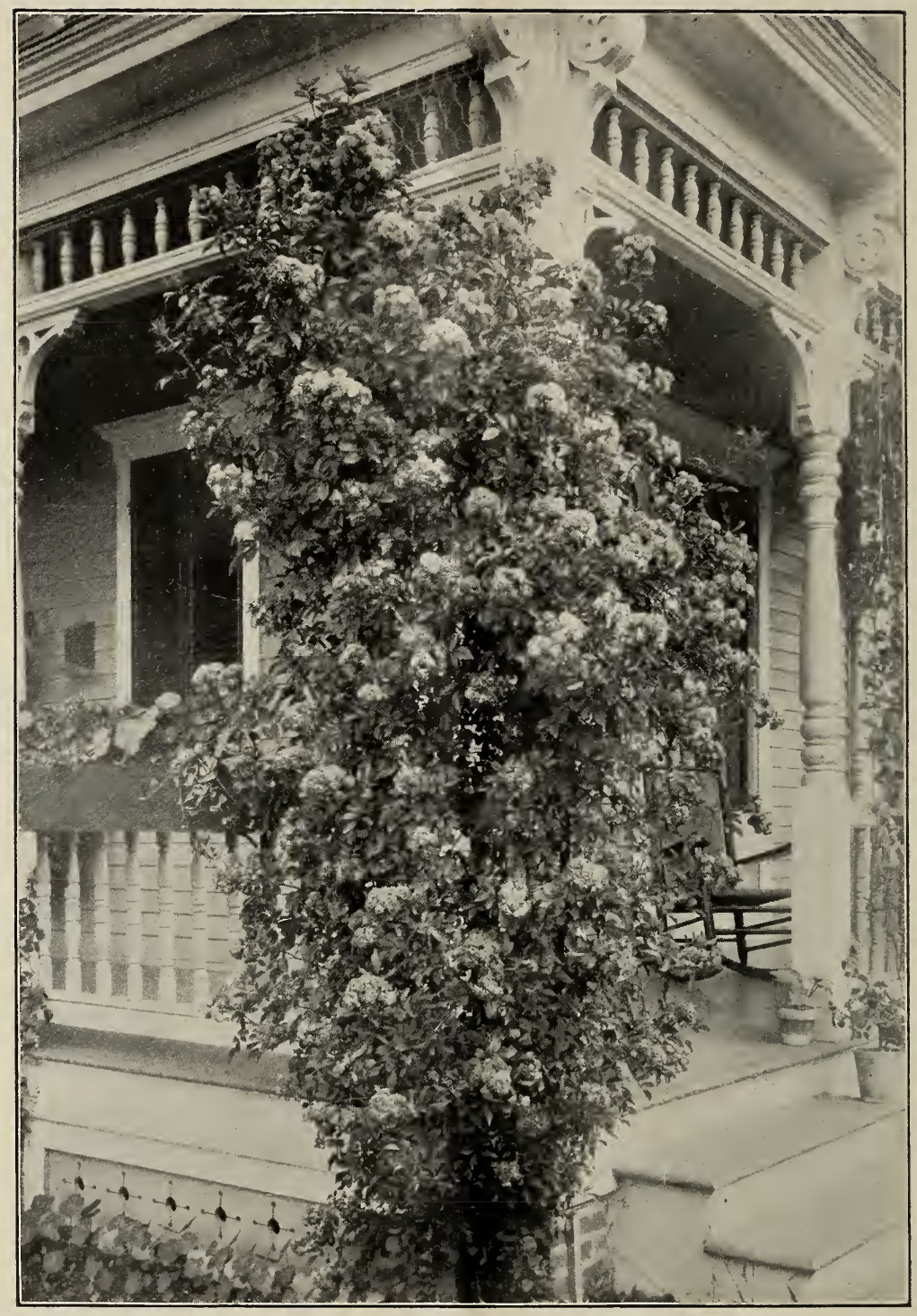

CRIMSON RAMBLER. 

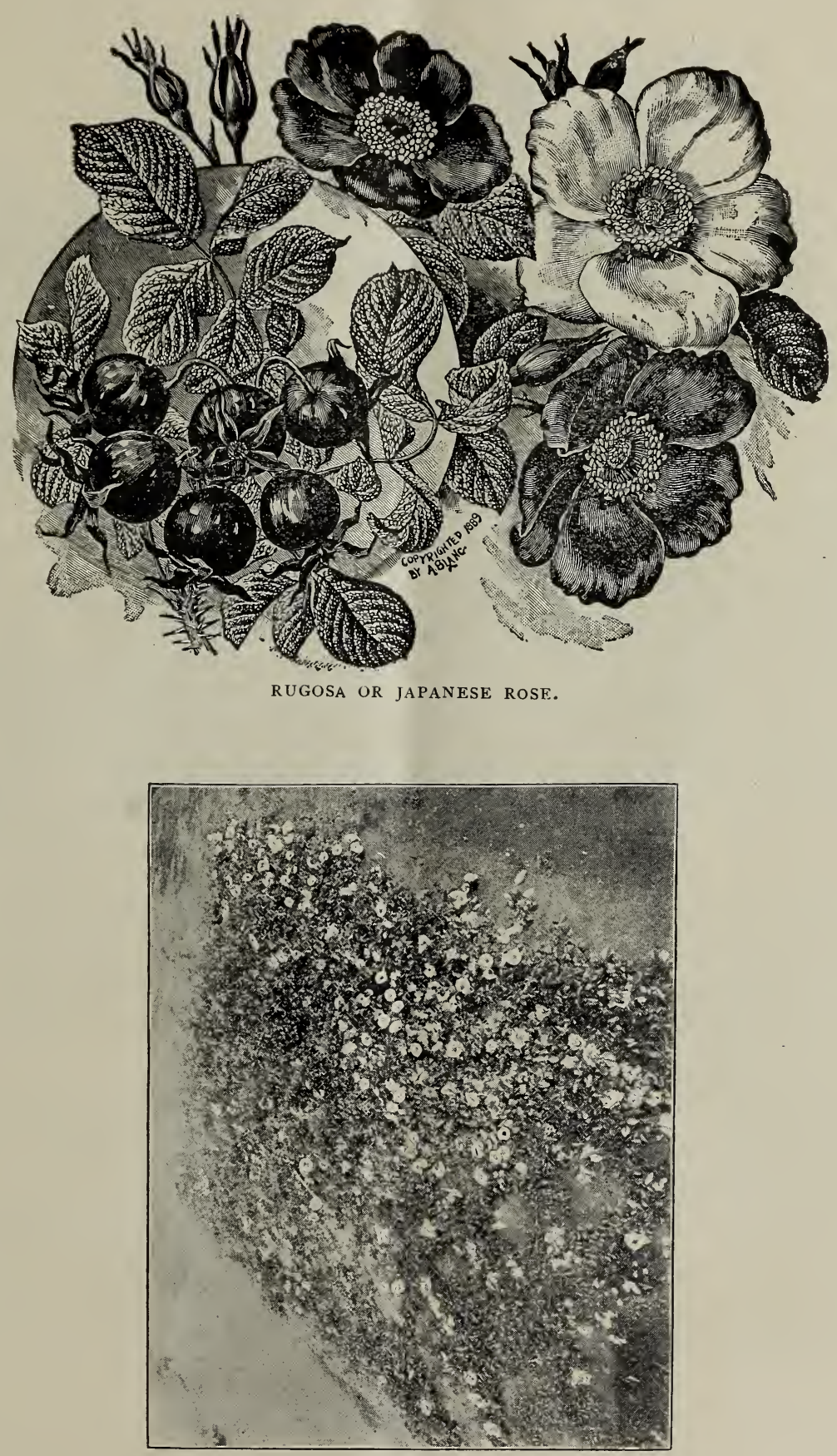

ROSA WICHURAIANA. 


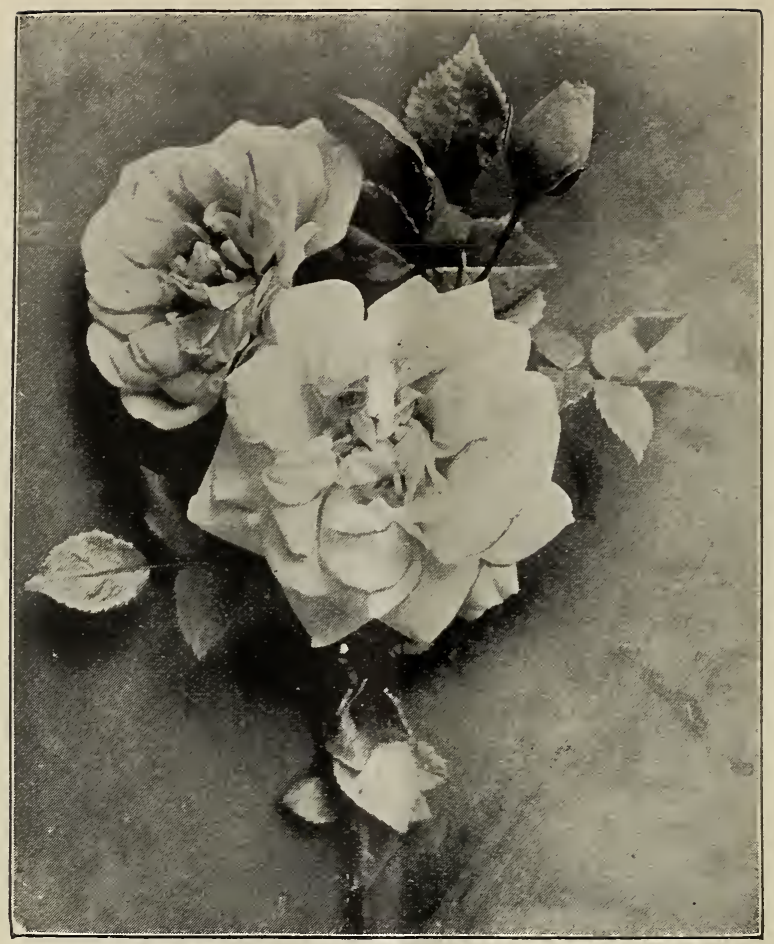

EVERGREEN RUSF, GARIIENIA.

\section{ROSA RUGOSA (Japanese Rose)}

A valuable species for grouping. It is a particularly attractive bush, with its dense mass of large, glossy leaves, which have a peculiar wrinkled appearance. Flowers 3 to 4 inches across, single, rosy red or white, followed by bright scarlet fruit. Strong, field-grown plants, $35 \mathrm{cts}$. each, $\$ 2.50$ per doz., \$I 8 per 100 .

\section{POLYANTHA ROSES}

These are of great value for bedding, as they give a mass of bloom from June till November. Their habit is dwarf; flowers small, produced in large clusters, often having 25 to 100 flowers.

Clothilde Soupert. Flowers large, very double; pearly white, shaded with pink toward center.

Little White Pet. Light pink, almost white.

Perle d'Or. Saffron yellow, tinged copper-color; strong plants. 35 cts. each, $\$ 3$ per doz.

\section{CHOICE CLIMBING ROSES}

Prairie Queen. Rosy Red, frequently with white stripes; double; a profuse bloomer.

Baltimore Belle. Flowers pure white, in large clusters.

Empress of China. A new, very valuable prepetual blooming climber. Flowers of medium size, very delicate; fragrant. The bnd is of especially fine form, dark pink in bud, lighter when open. Strong plants, 35 cts. each, $\$ 3$ per doz.

\section{NEW HYBRID WICHURAIANA ROSES}

The satisfaction that these new hybrids have given has created a general demand for them. They keep the same trailing habit, freedom of growth and fine glossy green foliage as the parent form, and are fully as hardy. They produce innumerable quanities of large, well-formed blooms, lasting a long time in prefection. Like Rosa Wichuraiana, they will grow in any soil, even on poor sandy or gravelly banks. 


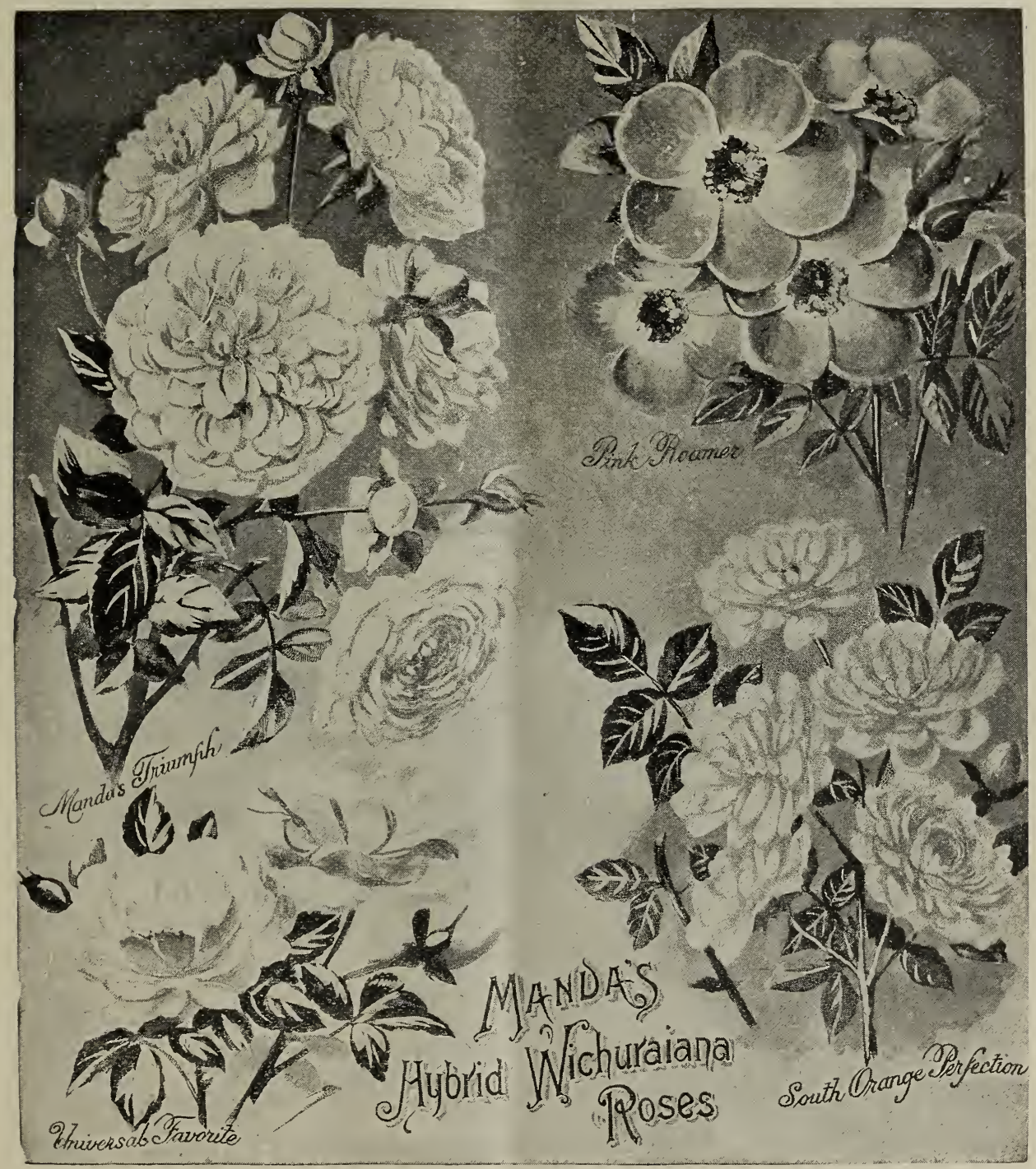


Manea's Triumph. Large clusters of well-formed double, pure white, fragrant flowers, two inches across.

Universal Favorite. Double flowers of a beautiful rose-color, over two inches across; fragrant.

South Orange Perfection. Multitudes of perfectly formed double flowers, nearly two inches across. Soft blush-pink at tips, changing to white.

Pink Roamer. Single flowers; bright pink; almost white center and orange-red stamens; very fragrant.

Strong, field.grown plants, of any of the above, $25 \mathrm{cts}$. each, $\$ 2$ per doz.

\section{NEW HARDY CLIMBING POLY- AN'THA ROSES}

Crimson Rambler. A wonderful new climbing Rose. An extremely vigorous grower and very hardy. Flowers medium size, bright crimson, pruduced in immense clusters which remain in perfection three to five weeks. Strong, field-grown plants, 35 cts. each, \$3 per doz.; extra large plants, 60 cts. each.

Yellow Rambler. The only hardy yellow climbing Rose. Similar in all respects to Grimson Rambler, except color, which is a clear, decided yellow in the bud, changing to cream when open. Flowers cupshaped, very fragrant, making it superior to Crimson Rambler in this respect. Strong plants, 35 cts. each, $\$ 3$ per doz.; extra size, $75 \mathrm{cts}$. each.

White Rambler. Another wonderful novelty from Japan. Flowers pure white, double and borne in great clusters. Strong plants, 25 cts. each $\$ 2.50$ per doz.

Dorothy Perkins. Another grand new and very desirable Rambler; flowers double, of a beautiful rose-pink; a good bloomer. $35 \mathrm{cts}$. each, $\$ 3$ per doz.

The set of four, one of each, \$r.25
Rosa Wichuraiana. The single, white Memorial Rose. A creeping species; flowers small; pure white; very fragrant; foliage bright glossy green. Valuable for covering banks, stumps, rockeries etc. Established plants make a growth of ten to twenty feet in a season. It will grow in very poor soil. Strong field-grown plants, 25 cts. each, \$2.25 per doz., \$I 5 per 100 .

\section{NEW EVERGREEN HYBRID WICHURAIANA ROSES}

A remarkable new set of Roses, of wonderfully free growth, a single specimen four years old covering a space of 240 square feet, with shoots $I 2$ to 25 feet in length. The foliage of all is leathery in texture, glossy, and not only free from insects, but nearly evergreen. The large fragrant flowers are produced very freely, and are extremely useful for cutting purposes.

For covering ground where nothing else will grow, to cover stumps, walls, trellises, etc., the following varieties will be found valuable:

Jersey Beauty. Wichuraiana $\times$ Perle des Jardins. Large single flowers, three inches in diameter; opening pale yellow, with bright yellow stamens; very fragrant.

Evergreen frem. Wichuraiana $X$ Mme. Host. Foliage rich, bronze-color, closely matted; flowers produced singly on stems; yellow, buff in bud, opening almost white, 2 to 3 inches in diameter; perfectly double, with delightful sweetbrier fragrance.

Gardenia, Wichuraiana $\times$ Perle des Jardins. Flowers produced single on stems six inches to one foot long; bright yellow in bud, cream-color when open; about three inches across; delightfully fragrant. Strongs plants, 35 cts. each, $\$ 3.00$ per doz.

\section{WATER-LILIES}

We recommend the following as the best for general cultivation. These can be successfuly grown in tubs. Information as to planting and care, on application.

Nymphaea odorata gigantea. Very large, white flowers, and large leaves; a superb variety. $35 \mathrm{cts}$. each, $\$ 3$ per doz.

N. odorata rosea. Flowers large size, cup-shaped; lovely deep pink in color; deliciously fragrant; a free bloomer. $75 \mathrm{cts}$. each, $\$ 8$ per doz.

N. Marliacea chromatella. A charming variety. The leaves are mottled brown when in a young state. Its large, fragrant flowers, which are a beautiful clear yellow, with bright orange stamens, are produced from spring till destroyed by frost. $75 \mathrm{cts}$. each, $\$ 8$ per doz. 


\section{FRUIT DEPARTMENT}

For want of space, we list only the best tested varieties. We can, however, furnish a number of varieties not listed. Descriptions and other information given if desired. Write for price in quantity before ordering; we probably can save you money.

\section{APPLES}

First-class, $;$ to $7 \mathrm{ft}$., 35 ea., $\$ 3$ per doz. \$2o per roo; extra bearing size, $50 \mathrm{cts}$. to $\$$ i ea.

Summer Varieties. Yellow Transparent, Early Harvest, Red Astrachan, Sweet Bough.

Autumn Varieties. Fall Pippin, Gravenstein, Alexander, Maiden's Blush, Twenty Ounce Pippin, Fameuse, Fallawater.

Winter Varieties. Baldwin, Ben Davis, Golden and Roxbury Russet, King, Mann, Spy, Newton Pippin, R. I. Greening, etc.

\section{CRAB APPLES}

First-class, 5 to $7 \mathrm{ft}$., $40 \mathrm{cts}$. each, $\$ 4$ per doz.

Hyslop, Martha, Large Red Siberian,

Yellow Siberian, Transcendent, Orange, etc.

\section{PEARS}

First-class, 5 to $7 \mathrm{ft}$., 50 cts. each, $\$ 5$ per doz., \$35 per ioo.

Summer Varieties. Brandywine, Clapp's Favorite, Doyenne d'Ete, Osband's Summer. Wilder.

Autumn Varieties. Bartlett, Bosc, Anjou, Frederick Clapp, Howell, Idaho, Seckel, Sheldon, Duchess.

Winter Varieties. Kieffer, Lawrence, Beurre Clairgeau.

Dwarf Pears. Duchess, Anjou, Bartlett, etc, 25 cts.

\section{PLUMS}

European Varieties. Bradshaw, Ger man Prune, Imperial Gage, Damson, Yellow Egg, Prince of Wales. First-class, 4 to $5 \mathrm{ft}$., $50 \mathrm{cts}$. each, $\$ 5$ per doz.

Japan Varieties. These are less subject to disease, said to be proof against insects. They are extremely prolific and very hardy. Burbank, Abundance, or Bhotan, Wickson, Hale, Satsuma, etc. 60 cts. each, $\$ 5.50$ per doz.

\section{CHERRIES}

First-class, 5 to $7 \mathrm{ft}$., 75 cts. ea., $\$ 6$ per doz.

Sour Varieties. Early Richmond, Late Duke, May Duke, Louis Phillippi, Montmorency.

Sweet Varieties. Black Tartarian, Coe's Transparent, Gov. Wood, Napoleon Bigarreau, Rockport Bigarreau, Windsor, Yellow Spanish.

\section{PEACHES}

Leading Sorts. First-class, $25 \mathrm{cts}$. each, $\$ 2$ per doz., \$10 per 100 .

\section{APRICOTS}

Russian Varieties. First-class, $40 \mathrm{cts}$. each, St per doz.

\section{QUINCES}

Orange and Champion. $40 \mathrm{cts}$. each, $\$ 4$ per doz.

Meech's. 40 cts. each, \$4 per doz.

\section{MULBERRIES}

Russian and New American. $50 \mathrm{cts}$. each, $\$ 4.50$ per doz.

Downing's Everbearing. 75 cts. each, \$6 per doz.

\section{NUT TREES}

Butternut and Black Walnut. $50 \mathrm{cts}$. Chestnut, American. Sweet, 6 to $S$ $\mathrm{ft}$., $50 \mathrm{cts}$. each, $\$ 4.50$ per doz.

C. Japan Giant. $4 \mathrm{ft}, \mathrm{s}$. .50 .

C., Spanish. 4 to $5 \mathrm{ft}$., $60 \mathrm{cts}$.

English Walnut. 4 to $5 \mathrm{ft} ., \$ 1.25$.

\section{SMALL FRUITS}

Blackberries. Early Harvest, Wilson's Early, Erie, Kittatinny, etc. 75 cts. per doz., \$4 per 100.

Raspberries, Red. 75 cts., per doz., \$3.50 per I00. Black. $75 \mathrm{cts}$. per doz., $\$ 4$ per 100.

Gooseberries. Downing, Smith's Improved, Red Jacket, Mountain, etc., 2 years, $\$ 1.50$ per doz.

Pear1. The wonderfully prolific new Gooseberry. \$z per doz.

Currants. Cherry, White Grape, Black Naples and Fay's Prolific, etc. 2 years, \$I.50 per doz.

\section{GRAPE-VINES}

2- and 3-year-old plants, first-class. B., black; W., white; R., red.

Agawam, R.; Prentiss, W.; Moore's Early, B. $20 \mathrm{cts}$. each, \$2 perdoz.

Concord, B.; Clinton, B.; Champion, B. 15 cts. each, \$I.50 per doz.

Delaware, R.; Pocklington, W. 20 cts. each, $\$ 2$ per doz.

Martha, Empite State and Niagara. W. 25 cts. each, \$I.75 per dcz.

Moyer, R. New. $25 \mathrm{cts}$. each, $\$ 2$ per doz. Moore's Diamond, IV. New. $30 \mathrm{cts}$. each, $\$ 2.25$ per doz.

Salem and Brighton, R. 25 cts. each, \$2 per doz.

Campbell's Early, B. New. Pulp sweet; seeds part readily. I year, 35 cts. each; 2 year, $50 \mathrm{cts}$. each. 


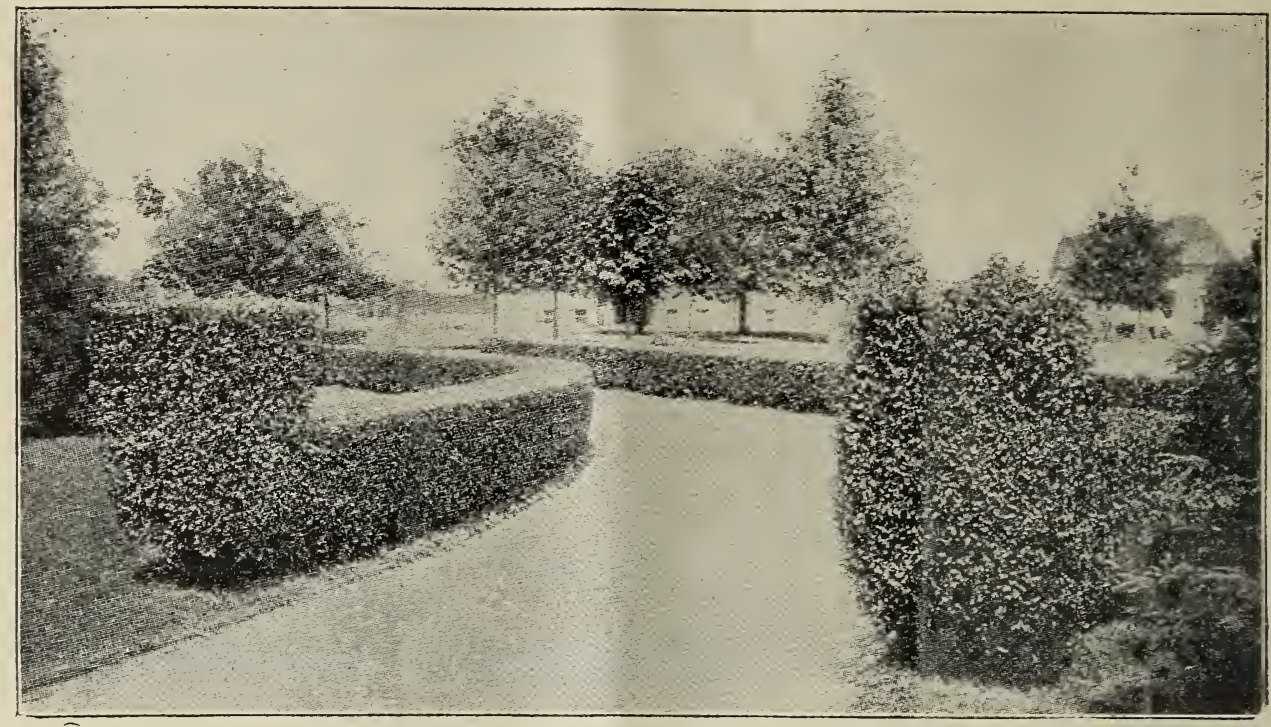

\section{LANDSCAPE ARCHITECTURE}

After some years of experience in this line we are prepared to execute any contemplated landscape work upon the most favorable terms.

Upon application, a competent man will visit and inspect either old or new places with a view to planting or remodeling.

Plans and estimates cheerfully furnished -upon visit or receipt of specification-for any desired work of this kind, for which no charge will be made, provided all the stock is supplied by us.

It is our custom to guarantee our planting for one year, and we replace free of charge any trees or plants failing to grow within that time, unless damaged by carelessness after work is finished. This gives the customer full protection, and insures the planting of strong, healthy stock.

Many country places may be wonderfully improved, at a very moderate expense, by the efforts of an intelligent person, experienced in this line, by having stock, planning and planting come under one contract.

We respectfully solicit your correspondence.

\section{EUGENE O. PETERSON, Manager, MONTROSE, N. Y.}


1.

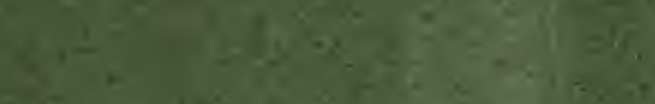

8.

$-8$

$1=$

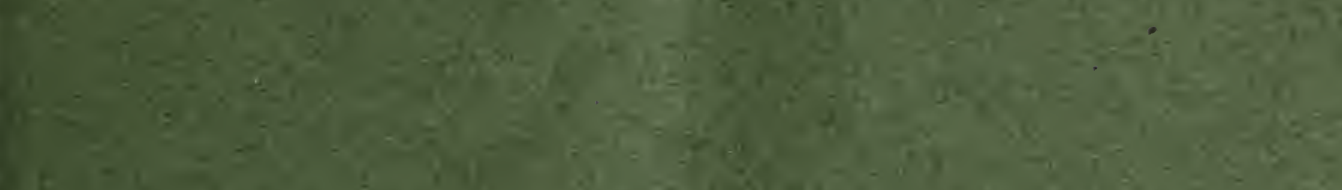

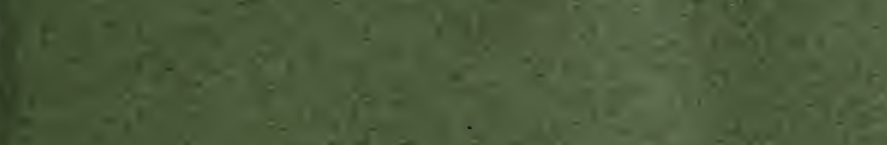

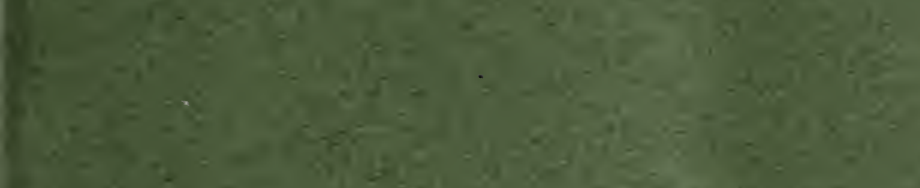

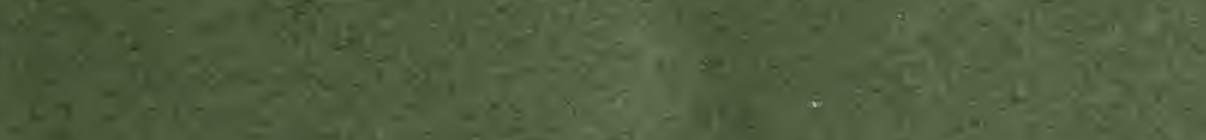

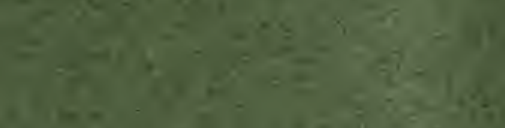

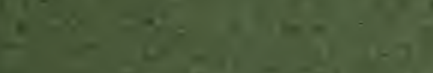

$(1.5)$

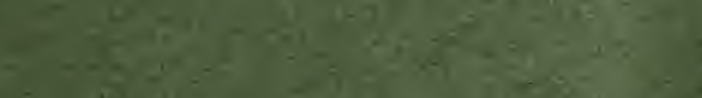

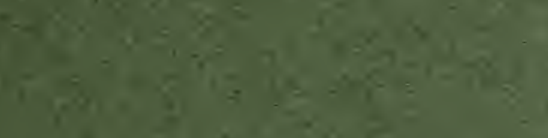

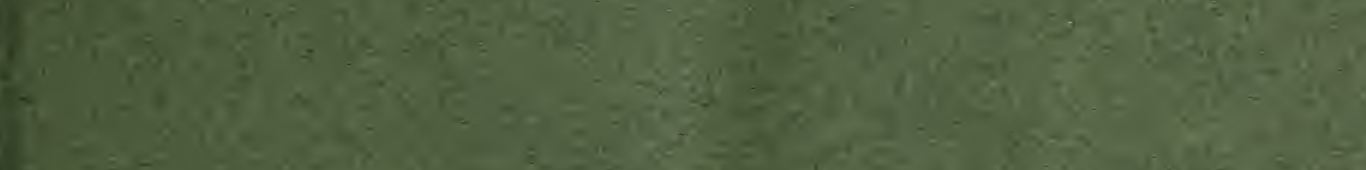
Sas if $x^{2}+4=$

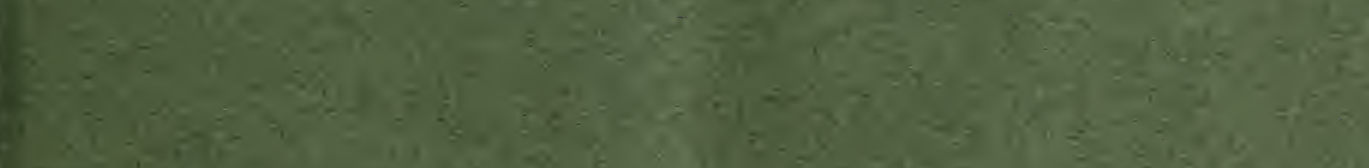

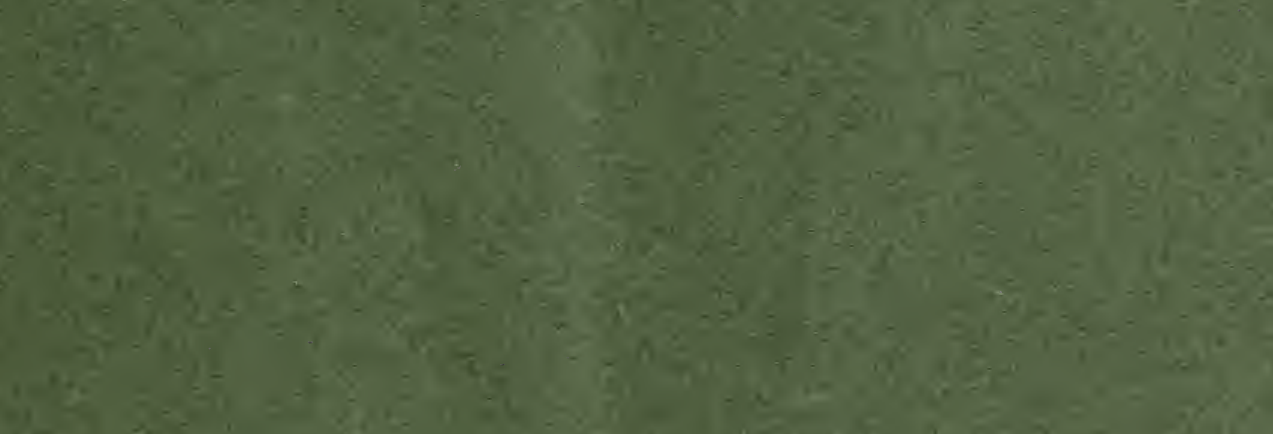

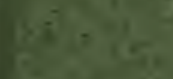

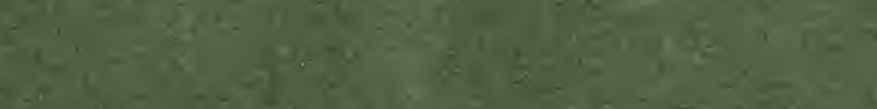

$$
\begin{aligned}
& i^{1}+200^{2}
\end{aligned}
$$

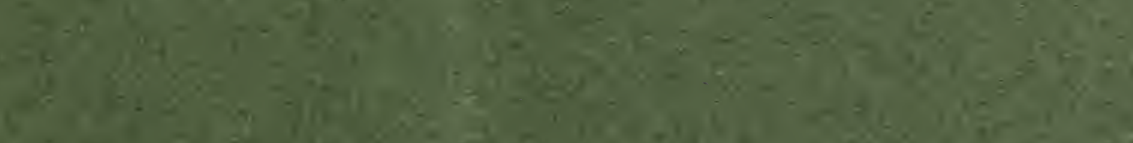

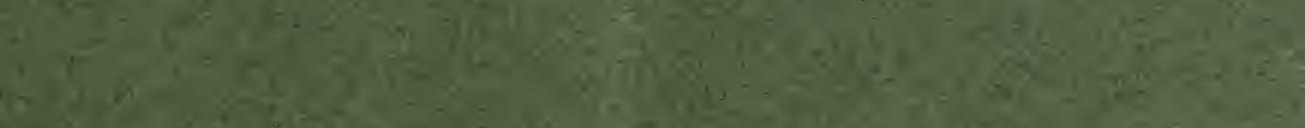

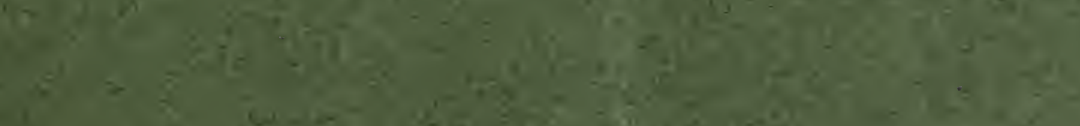
H.

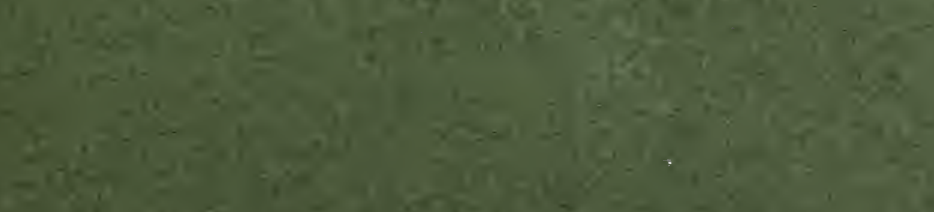

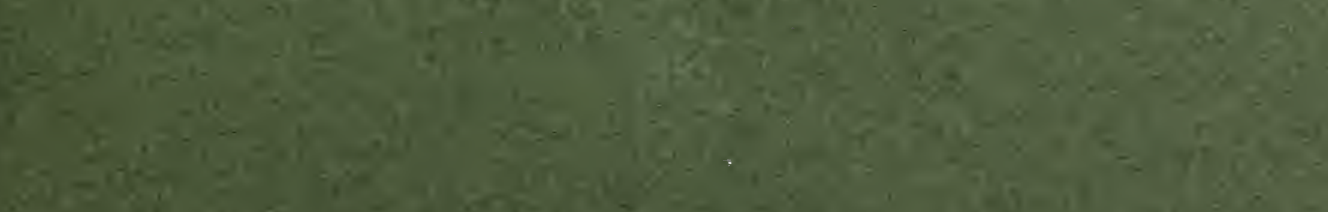

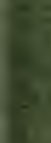




\section{Montrose Nurserieg MONTROSE}

\section{Westchester County, New York}

